\title{
LINGUISTIK KORPUS KUANTITATIF DAN KAJIAN SEMANTIK LEKSIKAL SINONIM EMOSI BAHASA INDONESIA
}

\author{
Gede Primahadi Wijaya Rajeg \\ Universitas Udayana, Indonesia \\ primahadi_wijaya@unud.ac.id
}

\begin{abstract}
This paper demonstrates the application of Multiple Distinctive Collexeme Analysis (MDCA) to study nuances and similarity between HAPPINESS near-synonyms in Indonesian. MDCA, as a variant of a family of quantitative corpus linguistic method called Collostructional Analysis, is proposed as a usage-based operationalisation for a classic theoretical construct in cognitive linguistic approach to emotion semantics, namely the idea of "related concepts" associated with the meaning of an emotion. Using MDCA, I expanded the idea of "related concepts" to investigate the semantics of more than one, near-synonymous, emotion on the basis of the synonyms' distinctive collocates. I argue that MDCA (i) provides empirical basis for such a theoretical idea as "related concepts" and (ii) helps enrich semantic characterisation of a given emotion word in comparison to its synonyms, highlighting how they may differ or converge semantically.

Keywords: Quantitative Corpus Linguistics; Multiple Distinctive Collexeme Analysis; Near-synonyms; HAPPINESS; Indonesian
\end{abstract}

\begin{abstract}
Abstrak
Makalah ini menampilkan penerapan analisis koleksem khas berganda (MDCA) guna menelusuri perbedaan dan kemiripan semantis di antara sinonim KEBAHAGIAAN bahasa Indonesia. MDCA, sebagai varian dari metode linguistik korpus kuantitatif bernama analisis kolostruksional, diajukan sebagai landasan empiris bagi ide teoretis klasik dalam pendekatan linguistik kognitif guna mengkaji makna emosi; ide ini disebut dengan "konsep terkait" yang mendasari pencirian makna suatu emosi. Dengan menggunakan MDCA, penulis memperluas ide "konsep terkait", yang diawali dengan kajian satu emosi, guna mengkaji makna lebih dari satu kata emosi yang juga sinonim berdasarkan kolokat khas dari sinonim tersebut. Penulis berpendapat bahwa MDCA (i) dapat menjadi salah satu landasan empiris untuk ide semantis "konsep terkait" dan (ii) memperkaya pencirian semantis suatu kata emosi ketika dibandingkan dengan sinonimnya yang lain, dengan menonjolkan bagaimana sinonim tersebut berbeda ataupun sejalan secara semantis.
\end{abstract}

Kata kunci: linguistik korpus kuantitatif; analisis koleksem khas berganda; sinonim; KEBAHAGIAAN; bahasa Indonesia

\section{PENDAHULUAN}

Salah satu perkembangan termutakhir dalam linguistik adalah keberadaan sumber data elektronik pemakaian bahasa alamiah dalam jumlah besar yang dikenal dengan istilah korpus. Kajian linguistik berdasarkan pemanfaatan data korpus ini kemudian disebut linguistik korpus (selanjutnya disingkat LKorp) (McEnery \& Hardie, 2012). Ukuran suatu korpus bahasa bisa 
mencapai ratusan juta bahkan triliunan kata. Hal tersebut memungkinkan kajian linguistik di segala lini dengan memanfaatkan informasi kuantitatif yang diperoleh melalui pengolahan data korpus berukuran besar.

Makalah ini bertujuan untuk menampilkan penerapan salah satu metode dalam linguistik korpus kuantitatif (Stefanowitsch \& Gries, 2005, hlm. 4-5) terhadap kajian semantik leksikal (i.e makna kata) sinonim emosi. Tujuan ini dapat memunculkan pertanyaan terkait bagaimana suatu hal yang bersifat konseptual dan subjektif, seperti makna kata, dapat dikaji melalui pendekatan kuantitatif (Glynn, 2014a). Penulis berpendapat bahwa tujuan tersebut dapat dicapai jika peneliti berorientasi pada pendekatan yang disebut usage-based linguistics (selanjutnya UBL) (Bybee, 2013; Langacker, 2013; Tummers dkk., 2005).

UBL pada hakikatnya mengutamakan pemakaian bahasa alamiah dalam (i) mengkaji struktur bahasa dan (ii) mengungkap sistem kebahasaan (seperti tata bahasa) (Tummers dkk., 2005, hlm. 229). Implikasi metodologis dari UBL adalah menjadikan data empiris pemakaian bahasa spontan (non-elicited/spontaneous language data) sebagai landasan untuk memodelkan struktur bahasa. Dengan kata lain, kejadian pemakaian bahasa alamiah (i) merupakan sumber dari semua unit-unit linguistik, (ii) membentuk sistem kebahasaan seseorang, dan kemudian (iii) mencerminkan kembali sistem kebahasaan tersebut (Langacker, 2013, hlm. 220; Bybee, 2013; Tummers dkk., 2005). Kerangka berpikir ini selaras dengan epistemologi dari LKorp yang berpijak pada data pemakaian bahasa alamiah (Tummers dkk., 2005, hlm. 232). Ini karena korpus bahasa adalah salah satu sumber data utama untuk kajian terhadap pemakaian bahasa spontan yang umum digunakan dalam kajian teoretis dan terapan dalam UBL (Gries, 2013).

Berikutnya, pertanyaan muncul terkait bagaimana asumsi dasar UBL di atas secara nyata dapat diterapkan dalam kajian semantik leksikal. UBL memandang bahwa makna suatu unit linguistik, seperti kata, tecermin dari distribusi konteks pemakaian kata tersebut (Glynn, 2014a). Konteks pemakaian di sini dapat berupa kata-kata atau struktur morfo-sintaksis yang sering muncul bersama dengan kata yang dikaji (Stefanowitsch, 2010, hlm. 368-370). Pandangan ini melanjutkan gagasan klasik dan fundamental dari John R. Firth, yaitu "you shall know a word by the company it keeps" dan dari Wittgenstein, yaitu "the meaning of a word is its use in the language" (Stefanowitsch, 2010, hlm. 368-370).

Pertanyaan selanjutnya adalah bagaimana pendekatan LKorp mengoperasionalkan konteks pemakaian kata sehingga dapat diamati dan kemudian diukur secara objektif pada data pemakaian bahasa. Salah satu teknik analisis utama dalam LKorp adalah kolokasi yang dapat digunakan untuk menemukenali pola leksikal dan gramatikal suatu kata, termasuk juga sinonim leksikal (Tummers dkk., 2005, hlm. 241). Linguis korpus dalam beberapa tahun terakhir telah mencoba mengembangkan teknik kuantitatif untuk menentukan pola kolokasi yang signifikan, seperti analisis kolostruksional (collostructional analysis/CollAna) (Gries \& Stefanowitsch, 2004; Hilpert, 2014; Stefanowitsch, 2013, 2014; Stefanowitsch \& Gries, 2003, 2005).

Dengan menggunakan salah satu ragam dari CollAna (lihat bagian Data dan Metodologi), makalah ini menyajikan (i) analisis kuantitatif atas kolokasi sinonim emosi, khususnya dalam medan leksikal konsep KeBAHAGIAAN (G. P. W. Rajeg, 2019a), serta (ii) bagaimana kolokasi khas dari tiap-tiap sinonim mencerminkan nuansa makna berbeda di antara sinonim tersebut, yang mungkin tidak bisa dengan seketika ditelusuri menggunakan intuisi kebahasaan. Ide metodologis dan analitis dalam makalah ini dapat diterapkan pada konsep emosi selain KEBAHAGIAAN. Konsep KEBAHAGIAAN dipilih untuk memberikan perbandingan 
terhadap hasil kajian kunci serupa dalam bahasa Inggris, yang juga menggunakan KEBAHAGIAAN sebagai titik awal (di antaranya Kövecses, 1991; Stefanowitsch, 2004).

Kajian dalam makalah ini akan berkontribusi terhadap perkembangan kajian semantik emosi melalui pendekatan linguistik korpus kuantitatif, yang sejauh ini lebih banyak dilakukan untuk rumpun bahasa Indo-Eropa (beberapa di antaranya Oster, 2010; Siepmann, 2014; Glynn, 2014b; Krawczak, 2014; Wilson \& Lewandowska-Tomaszczyk, 2017). Lebih lanjut, makalah ini juga menekankan peran linguistik korpus kuantitatif dalam menguji dan menjawab satu asumsi teoretis yang terkait dengan makna leksikon emosi, seperti yang diajukan oleh Kövecses (1990, 2015, hlm. 156-158) (lihat bagian selanjutnya). Terakhir, makalah ini bertujuan untuk mendorong lebih meluasnya praktik dan pola pikir terhadap sains terbuka (open science), utamanya untuk kajian di bidang bahasa dan linguistik di Indonesia. Semangat ini penulis tunjukkan dengan membagikan secara terbuka data dan kode pemrograman $\mathrm{R}$ (R Core Team, 2019) untuk analisis kuantitatif dalam makalah ini (lihat G. P. W. Rajeg, 2019c).

\section{KAJIAN PUSTAKA TEORETIS DAN METODOLOGIS}

Dua subbagian selanjutnya mengulas aspek teoretis dan metodologis makalah ini. Subbagian pertama memaparkan lebih lanjut asumsi teoretis yang diajukan oleh Kövecses (1990) terkait struktur semantis leksikon emosi serta isu operasionalisasinya secara empiris. Pemaparan ini dikaitkan dengan peran UBL dan LKorp sebagai kerangka konseptual dan metodologis untuk menguji dan mengoperasionalkan asumsi Kövecses (1990) tersebut. Subbagian kedua mengulas aspek metodologis dengan mengenalkan analisis kolostruksional (collostructional analysis) (untuk ulasan, periksa Hilpert, 2014; Stefanowitsch, 2013, 2014), khususnya salah satu ragam dalam CollAna yang digunakan dalam makalah ini, yaitu analisis koleksem khas berganda (multiple distinctive collexeme analysis) (Hilpert, 2006, 2008; Gilquin, 2010).

\section{Kajian Semantik Kognitif terhadap Leksikon Emosi oleh Kövecses (1990)}

Kövecses (1990) menjadi salah satu acuan kunci klasik untuk kajian semantik terhadap leksikon emosi dari sudut pandang linguistik kognitif (LKog) (Dąbrowska \& Divjak, 2015). Kövecses (1990, hlm. 198) menyimpulkan bahwa struktur semantis suatu kata emosi terbangun melalui (i) metafora, (ii) metonimi, dan (iii) konsep terkait (related/inherent concepts) dari emosi tersebut.

Metafora dalam LKog dipandang sebagai mekanisme kognitif dalam memahami ranah abstrak, seperti emosi, berdasarkan pengetahuan akan ranah eksperiensial, konkret, dan badaniah (Lakoff \& Johnson, 1980). Misalnya, konsep AMARAH di banyak bahasa di dunia dapat dipahami sebagai API (Kövecses, 2000; untuk bahasa Indonesia, periksa G. P. W. Rajeg, 2014; I. M. Rajeg, 2013; Yuditha, 2010, 2013). Metafora AMARAH ADALAH API di bahasa Indonesia (BI) tecermin dalam ekspresi linguistik metaforis berikut.

(1) Seluruh badanku panas! Panas terbakar api amarah. (I. M. Rajeg, 2013, hlm. 109)

(2) Karena pada saat itu api kemarahan berkobar membakar darah di hati. (G. P. W. Rajeg, 2014 Tabel 1)

(3) Sesungguhnya sedekah yang dilakukan secara diam-diam dapat memadamkan kemurkaan Allah Azza wa Jalla. (G. P. W. Rajeg, 2014 Tabel 1)

(4) Si lelaki masih terbakar, bukan sebab berahi, tetapi amarah. (Yuditha, 2010, hlm. 10)

Metonimi dalam LKog merupakan mekanisme kognitif yang melibatkan penggunaan suatu entitas (disebut source/vechicle) untuk menunjuk pada entitas lain (target) yang masih 
berkaitan (Lakoff \& Johnson, 1980, Bab 8). Satu contoh metonimi dalam BI adalah pemakaian kata wajah dalam wajah-wajah baru di persepakbolaan Indonesia. Pada contoh ini, sebagian entitas (wajah) digunakan secara implisit untuk menunjuk pada keseluruhan entitas (dalam hal ini orang). Dalam ranah emosi, penanda metonimis untuk suatu emosi umumnya bersumber pada frase atau kata-kata untuk reaksi perilaku, ekspresif, dan fisiologis, yang diasumsikan mengikuti kemunculan emosi tersebut. Contohnya, ungkapan terkait reaksi fisiologis, seperti kejadian itu membuat bulu kuduk berdiri atau penurunan suhu tubuh keringat dingin, secara metonimis menunjuk pada RASA TAKUT dalam BI karena reaksi-reaksi tersebut dianggap muncul dengan rasa takut.

Konsep-konsep terkait (related concepts) dibatasi sebagai "konsep-konsep yang tersirat atau disyaratkan oleh konsep lainnya" (Kövecses, 1990, hlm. 128). Konsep-konsep terkait ini dipandang membentuk jejaring konsep yang diasosiasikan dengan konsep emosi yang dikaji (lihat juga Kövecses, 2015, hlm. 158). Contoh yang diberikan Kövecses (1990, hlm. 41) adalah konsep-konsep terkait dengan CINTA, yang meliputi PERTEMANAN, RASA HORMAT/RESPEK, KEINTIMAN, KASIH SAYANG (affection), HASRAT SEKSUAL, dan ANTUSIASME. Untuk KEBAHAGIAAN (HAPPINESS) dalam bahasa Inggris (BIng), Kövecses (2015, p. 162) mengajukan tiga konsep terkait, yaitu KEPUASAN (SATISFACTION), KESENANGAN (PLEASURE), dan KESELARASAN (HARMONY).

\section{Inti Permasalahan dan Solusi Metodologis}

Makalah ini tidak sepenuhnya membahas peran metafora dan metonimi terkait makna emosi (periksa G. P. W. Rajeg, 2014, 2019a; I. M. Rajeg, 2013; Siahaan, 2008; Yuditha, 2010, 2013, untuk kajian metafora emosi Bahasa Indonesia berbasis korpus). Isu yang diangkat adalah bahwa Kövecses (1990) tampaknya tidak menjelaskan secara nyata landasan empiris (misalnya data dan metode empiris) yang digunakan untuk menentukan "konsep terkait" yang turut membangun makna suatu emosi. Introspeksi intuitif tampaknya mendasari argumen Kövecses (2015), misalnya, dalam mengajukan bahwa KEPUASAN, KESENANGAN, dan KESELARASAN menjadi konsep-konsep terkait dari KEBAHAGIAAN. Pertanyaan yang muncul adalah bagaimana asumsi mendasar UBL (usage-based linguistics) dan metode LKorp memfasilitasi operasionalisasi empiris untuk "konsep terkait" dalam pencirian semantis suatu leksikon emosi?

Seperti disebutkan pada bagian Pendahuluan, UBL memandang bahwa makna kata dapat dicirikan berdasarkan konteks pemakaiannya; kolokasi (yaitu kata-kata yang sering muncul di sekitar kata target) merupakan salah satu operasionalisasi dari "konteks pemakaian" suatu kata dalam korpus. Kajian Oster (2010) terhadap kata fear 'rasa takut' sebagai nomina dalam bahasa Inggris ragam Amerika menunjukkan bahwa kolokasi signifikan (secara statistik) dapat digunakan sebagai pencirian konsep terkait yang menjadi bagian dari makna dan pemakaian suatu leksikon emosi. Oster (2010, hlm. 732) menjelaskan bahwa dalam pemakaiannya, suatu leksikon emosi memiliki kecenderungan kuat untuk berkolokasi dengan kata-kata lain yang juga berasal dari ranah EMOSI/PERASAAN. Dalam kasus fear, Oster (2010, hlm. 752) menemukan kecenderungan kuat kolokat yang bernuansa negatif untuk muncul bersama fear, seperti horror 'horor', wariness 'kecurigaan', despair 'keputusasaan', dan paranoia 'takut berlebih'. Kolokasi ini diistilahkan dengan "kedekatan konseptual" (conceptual proximity) (Oster, 2010, hlm. 732, 752), yang secara teoretis bertalian dengan "konsep terkait" (related concepts) yang diajukan oleh Kövecses (1990). 
Makalah ini (i) berangkat dari kajian kolokasi Oster (2010) yang hanya mengamati satu emosi dan (ii) memperluas perspektif kajiannya dalam konteks sinonim emosi bahasa Indonesia. Makalah ini akan menunjukkan bagaimana kolokat khas (distinctive collocates) dari suatu emosi memberikan pencirian semantis khas untuk emosi tersebut jika dibandingkan dengan sinonimnya. Teknik yang digunakan untuk mengetahui kolokasi khas adalah multiple distinctive collexeme analysis (selanjutnya disebut MDCA) atau analisis koleksem khas berganda (Hilpert, 2006, 2008), salah satu ragam dari CollAna yang akan diulas pada bagian selanjutnya.

\section{Analisis Kolostruksional (Collostructional Analysis [CollAna])}

Analisis kolostruksional (CollAna) dirancang untuk mengkaji makna konstruksi gramatikal berdasarkan unsur leksikal yang kuat secara statistik muncul di dalam konstruksi tersebut (Hilpert, 2014; Stefanowitsch, 2013, 2014). CollAna terinspirasi dari analisis kolokasi leksikal yang mengkaji keterkaitan antara satu kata dengan kata lainnya dan menerapkannya dalam konteks konstruksi gramatikal (Stefanowitsch \& Gries, 2009). CollAna bukanlah label untuk satu teknik analisis, tetapi mencakup tiga gugusan teknik analisis kuantitatif terkait, yaitu (i) simple collexeme analysis (SCA) (Stefanowitsch \& Gries, 2003), (ii) distinctive collexeme analysis (DCA) (Gries \& Stefanowitsch, 2004), dan (iii) covarying collexeme analysis (CCA) (Stefanowitsch \& Gries, 2005). Meskipun seluruh ragam dari CollAna dilandasi atas metode statistik yang serupa (yaitu, statistik distribusional dengan Fisher Exact Test dan Binomial Test), tiap-tiap ragam dirancang untuk menjawab subpertanyaan teoretis yang berbeda terkait hubungan antara unsur leksikal dan konstruksi gramatikal (Stefanowitsch, 2013, hlm. 291).

SCA digunakan untuk mengungkap asosiasi statistik antara suatu slot dalam konstruksi gramatikal dan unsur leksikal yang dapat mengisi slot tersebut. Sebagai contoh, Stefanowitsch dan Gries (2003) menemukan bahwa slot predikat dalam konstruksi dwitransitif bahasa Inggris paling kuat berasosiasi dengan verba give (mengindikasikan makna 'transfer' dari konstruksi tersebut), dan beberapa verba lainnya, seperti send, offer, owe, promise, tell, teach, show, cost, deny (lihat Stefanowitsch \& Gries, 2003, hlm. 227-230 untuk ulasan lebih jauh).

DCA merupakan perluasan teknik kolokat khas yang dikembangkan oleh Church dkk. (1991) untuk mengungkap perbedaan semantis di antara sinomin leksikal. Metode kolokat khas mengamati semua kolokat dari dua sinonim leksikal dan membandingkan frekuensi kemunculan kolokat tersebut dengan kedua sinonim untuk menentukan daya asosiasi (association strength) suatu kolokat terhadap satu dari kedua sinonim. Metode kolokat khas ini kemudian akan menghasilkan daftar kolokat yang khas menjadi pembeda semantis antara kedua sinonim. Dalam konteks konstruksi gramatikal, DCA mengadaptasi kolokat leksikal khas untuk membandingkan dua konstruksi gramatikal yang mirip secara semantis/fungsional (misalnya, konstruksi alternasi will + inf vs be going to + inf; konstruksi preposisi datif vs konstruksi dwitransitif; atau konstruksi aktif vs pasif). Sebagai contoh, Stefanowitsch (2013, hlm. 297) menunjukkan bahwa bring, play, take, pass, dan sell merupakan beberapa verba yang khas muncul dengan konstruksi preposisi datif (bring/take/sell Xtema to Ylokatif/penerima), sedangkan give, tell, show, offer berasosiasi kuat dengan pola dwitransitif (offer/give $Y_{\text {penerima }} X_{\text {tema }}$ ) (Untuk penerapan DCA atas data bahasa Indonesia, lihat G. P. W. Rajeg dkk., 2018; G. P. W. Rajeg \& Rajeg, 2019a).

CCA bertujuan untuk mengidentifikasi sepasang kata yang muncul bersama secara lebih sering/jarang dari yang diharapkan dalam dua slot dari satu konstruksi gramatikal. Kedua slot dalam konstruksi tersebut menyediakan bingkai sintaksis guna mengkaji asosiasi sepasang kata. 
Salah satu contoh penerapan CCA adalah kajian terhadap pasangan kata yang mengisi slot (i) predikat utama dan (ii) pelengkap preposisi verbal dari konstruksi "into-causative" dalam bahasa Inggris. Contoh berikut disitir langsung dari Stefanowitsch \& Gries, 2005, hlm. 11).

(5)

$\begin{array}{lllll}\text {... he was forced } & \text { into making } & \text { a } & \text { reluctant } & \text { announcement } \\ \text {...dia AUXpaksa.PASS } & \text { ke.dalam membuat } & \text { ART } & \text { enggan } & \text { pengumuman }\end{array}$

'... dia dipaksa hingga membuat pengumuman yang dia sebenarnya enggan ungkapkan'

(6) Newley had been tricked into revealing his hiding place

NAMA AUX AUX tipu.PASS ke.dalam mengungkap POSS sembunyi tempat

'Newley telah ditipu hingga mengungkap tempat persembunyiannya'

Forced dan tricked pada contoh di atas merupakan verba yang menyatakan penyebab terjadinya (causing event) kejadian yang diungkapkan oleh making dan revealing (resulting event). CCA akan menghasilkan daftar kombinasi verba penyebab (causing event) dan verba ing (resulting event) yang saling berasosiasi dalam konstruksi "into-causative". Beberapa contoh kombinasi terkuat yang ditemukan oleh Stefanowitsch dan Gries (2005, hlm. 13) adalah fool into thinking, mislead into thinking, mislead into believing, dan deceive into thinking.

Mengingat makalah ini mengkaji pencirian semantis untuk lebih dari dua nomina sinonim KEBAHAGIAAN berdasarkan pola kolokasinya, metode dari CollAna yang akan diterapkan adalah perluasan dari DCA yang disebut multiple distinctive collexeme analysis (MDCA) atau analisis koleksem khas berganda. MDCA dibahas pada subbagian selanjutnya.

\section{Analisis Koleksem Khas Berganda (Multiple Distinctive Collexeme Analysis [MDCA])}

MDCA memperluas cakupan DCA untuk membandingkan kolokat/koleksem khas dari lebih dari dua konstruksi (gramatikal ataupun leksikal) yang mirip secara semantis/fungsional (Hilpert, 2006; Stefanowitsch, 2013) (lihat juga Goldberg, 2013, hlm. 17 untuk pemaparan terkait status kata sebagai konstruksi). MDCA telah diterapkan pada kajian-kajian terkait konstruksi gramatikal di bahasa-bahasa Indo-Eropa. Hilpert $(2008,2006)$ membandingkan preferensi kolokasional dari sejumlah konstruksi future di bahasa Jermanik pada korpus diakronik. Gilquin (2010) membandingkan konstruksi kausatif perifrastik bahasa Inggris dengan verba make, have, get, dan cause. Analisisnya terpusat pada pelengkap verbal dari verba kausatif tersebut di dalam konstruksinya. Desagulier (2014) mengkaji kolokat adjektival khas yang dapat diterangkan (modified) oleh adverbial rather, quite, pretty, dan fairly. Terakhir, Levshina (2015, hlm. 248) mengkaji satu konstruksi [quite + ADJ] dan membandingkan unsur leksikal khas pengisi slot adjektiva pada tiga ragam bahasa Inggris (Amerika, Britania, dan Kanada). Untuk data bahasa Indonesia, landasan kuantitatif pada MDCA telah diterapkan dalam konteks kajian interaksi antara metafora dan sinonim emosi (G. P. W. Rajeg, 2019a, Bab 7, 2014).

Subbagian ini akan mengulas secara lebih terperinci landasan kuantitatif dari MDCA, yaitu one-tailed exact binomial test (uji binomial). Sebagai contoh, akan dipaparkan bagaimana uji binomial digunakan untuk mengukur daya asosiasi (association strength) atau kekhasan (distinctiveness) kata anak-anak sebagai kolokat yang muncul dalam lingkup empat kata di sebelah kanan dan kiri dari keceriaan, yaitu salah satu dari sepuluh sinonim KEBAHAGIAAN yang dikaji (lihat Tabel 3 dan perhatikan pula Tabel 1). Suatu kolokat dikatakan khas untuk (atau kuat berasosiasi dengan) suatu sinonim apabila kolokat tersebut muncul dengan sinonim 
yang dimaksud (jika dibandingkan dengan sinonim lain) lebih sering daripada yang diharapkan atas dasar kebetulan.

Tabel 1 Luaran MDCA untuk Daya Asosiasi Anak-Anak sebagai Kolokat dari Sinonim KEBAHAGIAAN

\begin{tabular}{|c|c|c|c|c|c|c|c|c|}
\hline no. & kolokat & Sinonim & $\mathbf{n}$ & $\exp$ & assocstr & p_binomial & p_holm & Signif \\
\hline 1 & anak-anak & bahagia & 3 & 7.973 & -1.406 & $3.926 \mathrm{e}-02$ & $1.000 \mathrm{e}+00$ & Ns \\
\hline 2 & anak-anak & ceria & 1 & 0.835 & 0.246 & $5.672 \mathrm{e}-01$ & $1.000 \mathrm{e}+00$ & Ns \\
\hline 3 & anak-anak & gembira & 0 & 3.640 & -1.601 & $2.508 \mathrm{e}-02$ & $1.000 \mathrm{e}+00$ & Ns \\
\hline 4 & anak-anak & kebahagiaan & 16 & 56.554 & -13.189 & $6.477 \mathrm{e}-14$ & $4.720 \mathrm{e}-09$ & $* * *$ \\
\hline 5 & anak-anak & keceriaan & 91 & 19.123 & 42.698 & $2.003 e-43$ & $1.460 \mathrm{e}-38$ & $* * *$ \\
\hline 6 & anak-anak & kegembiraan & 15 & 22.552 & -1.320 & $4.789 \mathrm{e}-02$ & $1.000 \mathrm{e}+00$ & Ns \\
\hline 7 & anak-anak & keriangan & 17 & 6.770 & 3.331 & $4.665 \mathrm{e}-04$ & $1.000 \mathrm{e}+00$ & Ns \\
\hline 8 & anak-anak & kesenangan & 3 & 22.594 & -7.111 & $7.736 \mathrm{e}-08$ & $5.634 \mathrm{e}-03$ & $* *$ \\
\hline
\end{tabular}

Catatan untuk kolom pada Tabel 1: $\boldsymbol{n}$ (frekuensi kemunculan riil kolokat dalam lingkup empat kata di sebelah kiri dan kanan dari sinonim dalam kalimat); exp (frekuensi harapan kemunculan kolokat atas dasar distribusi acak (lihat G. P. W. Rajeg \& Rajeg, 2019b, hlm. 21-22 terkait frekuensi riil dan harapan)); assocstr (daya asosiasi atau kekhasan antara kolokat dan sinonim yang merupakan hasil logaritma10 negatif terhadap $p$-value dari tes binomial $\left[\boldsymbol{p} \_\right.$binomial $]$); $\boldsymbol{p} \_$holm (koreksi $p$-value dengan metode Holm terhadap p_binomial mengingat MDCA melibatkan uji signifikansi berulang; koreksi ini merupakan prosedur standar dalam statistik, tetapi tidak begitu ketat digunakan untuk kajian-kajian CollAna karena p_binomial hanya digunakan untuk perangkingan kolokat); signif (keputusan terkait signifikansi [berdasarkan $p_{-}$holm] dari daya asosiasi antara kolokat dan sinonim).

Frekuensi kemunculan riil (observed frequency) anak-anak dalam lingkup empat kata di kiri dan kanan keceriaan di dalam korpus adalah 91 kali. Selain frekuensi riil, uji binomial juga memerlukan frekuensi yang diharapkan muncul atas dasar distribusi acak untuk anak-anak dengan keceriaan; frekuensi ini disebut frekuensi harapan (expected frequency) (lihat G. P. W. Rajeg \& Rajeg, 2019b, hlm. 21-22). Untuk kasus kali ini, frekuensi harapan dihitung dengan cara (i) mengalikan frekuensi keceriaan di dalam data (yaitu 3,641) dengan total frekuensi kemunculan anak-anak dengan semua sinonim (yaitu 147), kemudian (ii) membagi hasil perkalian tersebut dengan total keseluruhan data kolokasi empat kata di kiri dan kanan kesepuluh sinonim (yaitu, 27,989). Jadi, frekuensi harapan untuk kemunculan anak-anak dengan keceriaan adalah $(3,641 * 147) / 27,989=19.123$.

Selisih antara frekuensi riil dan harapan digunakan untuk menentukan arah asosiasi antara suatu kolokat dengan sinonim yang dimaksud. Apabila selisihnya positif (yaitu frekuensi riil lebih tinggi dari frekuensi harapan), kolokat tersebut berasosiasi positif dengan, atau bersifat khas untuk, sinonim yang dikaji; sebaliknya, selisih negatif mengindikasikan disosiasi antara kolokat dan sinonim (Stefanowitsch, 2014, hlm. 227, 2013). Perbandingan frekuensi riil dan harapan untuk anak-anak dan keceriaan (baris kelima pada Tabel 1) menunjukkan asosiasi positif karena frekuensi riilnya (kolom n) lebih tinggi dari frekuensi harapannya (kolom exp): $91>19.123$. Asosiasi negatif, di antaranya, ditunjukkan oleh anak-anak dan kebahagiaan (baris keempat pada Tabel 1). 
Selain frekuensi riil dan harapan, uji binomial juga memerlukan probabilitas praanggapan (a priori probability), yang menunjukkan bahwa apabila muncul sebagai kolokat dalam rentang empat kata di kiri dan kanan sinonim KEBAHAGIAAN, anak-anak akan muncul dengan keceriaan (Hilpert, 2006, hlm. 247). Probabilitas ini dihitung dengan cara membagi (i) frekuensi harapan anak-anak dan keceriaan (yaitu 19.123) dengan (ii) total frekuensi kemunculan anak-anak dengan semua sinonim (yaitu 147) sehingga 19.123/147 =0.1301.

Selanjutnya, uji binomial akan menentukan signifikansi statistik dari asosiasi antara kolokat dan sinonim, yaitu apakah secara statistik suatu kolokat muncul secara signifikan lebih sering atau jarang dari yang diharapkan atas dasar suatu kebetulan. Nukilan kode pemrograman $\mathrm{R}$ berikut adalah cara menghitung pbinomial-value untuk uji binomial apabila frekuensi riil suatu kolokasi lebih tinggi dari frekuensi harapan, seperti halnya anak-anak dan keceriaan.

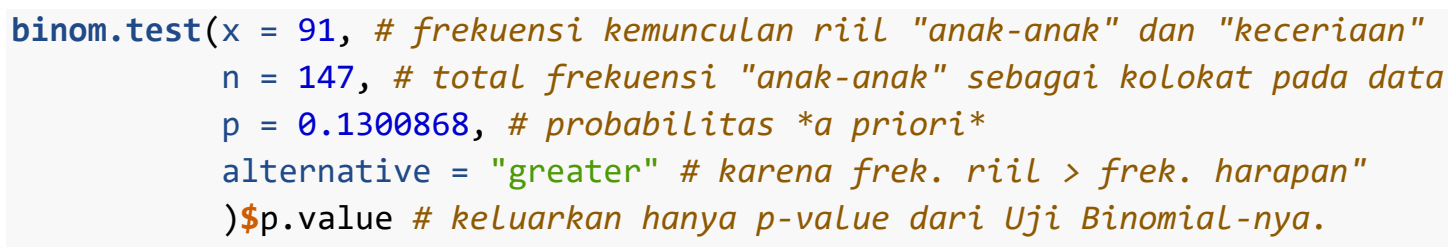

Nilai $p$ binomial-value menunjukkan probabilitas guna menemukan frekuensi kemunculan riil anak-anak dengan keceriaan dalam korpus, mengingat hipotesis kosong (null hypothesis) (lihat G. P. W. Rajeg \& Rajeg, 2019b, hlm. 19-20) menyatakan bahwa seharusnya keceriaan dan sinonim yang lain memiliki distribusi yang setara untuk berkolokasi dengan anak-anak (dapat dilihat pada Tabel 1 adanya ketimpangan distribusi untuk anak-anak terhadap tiap-tiap sinonim). Semakin kecil p-value (biasanya di bawah 0.05), semakin kuat asosiasi/kekhasan (atau disosiasi/ketidakhasan) antara suatu kolokat dengan sinonim yang dikaji. Probabilitas yang dihasilkan dari contoh uji binomial di atas sangatlah kecil ( $p$ binomial $<0.001)_{1}$ (perhatikan kolom p_binomial pada Tabel 1). (i) Frekuensi kemunculan riil anak-anak dengan keceriaan lebih tinggi daripada frekuensi yang diharapkan dan (ii) begitu kecilnya nilai probabilitas uji binomial di atas mengindikasikan asosiasi positif dan khas yang signifikan (tidak bisa dianggap sebagai suatu kebetulan) antara anak-anak dan keceriaan (periksa Tabel 8).

Berikut ini adalah nukilan kode $\mathrm{R}$ untuk uji binomial apabila frekuensi kemunculan riil lebih kecil dari frekuensi harapan, seperti halnya antara anak-anak dan kebahagiaan.

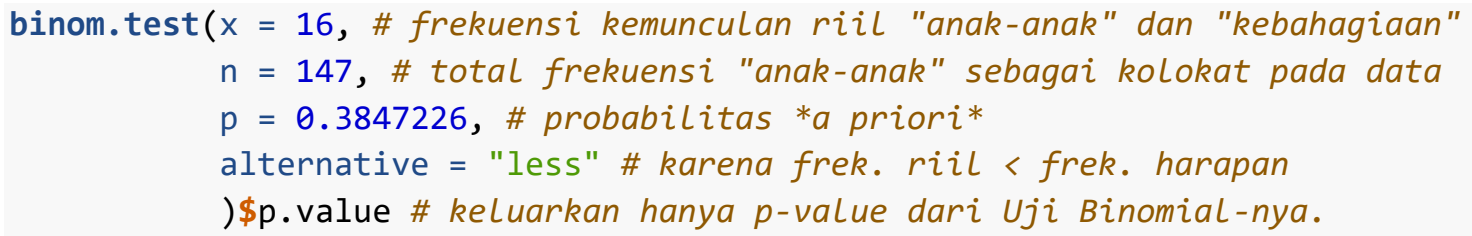

\#\#[1] $6.476552 \mathrm{e}-14$ 
\# kode alternatif yang menghasilkan p-value sama adalah sebagai berikut:

$\operatorname{sum}(\operatorname{dbinom}(0: 16,147,0.3847226))$

\#\#[1] $6.476552 \mathrm{e}-14$

Hasil di atas menunjukkan bahwa bukanlah suatu kebetulan apabila anak-anak memiliki ketidakterkaitan dengan kebahagiaan dalam sampel. Dengan kata lain, anak-anak muncul secara signifikan lebih jarang dari yang diharapkan sebagai kolokat untuk kebahagiaan dalam sampel.

Untuk kemudahan intuitif dalam memahami nilai $p$-value sebagai derajat kekhasan suatu kolokat, CollAna menggunakan nilai logaritma10 negatif dari $p$-value yang dihasilkan dan mengistilahkan konversi nilai tersebut dengan daya asosiasi (association strength) atau kekhasan (distinctiveness) (perhatikan kolom assocstr pada Tabel 1) (Stefanowitsch \& Gries, 2005, hlm. 7; Hilpert, 2006, hlm. 247). Nukilan kode R berikut mencontohkan pengubahan pbinomial-value dalam bentuk nilai logaritma 10 .

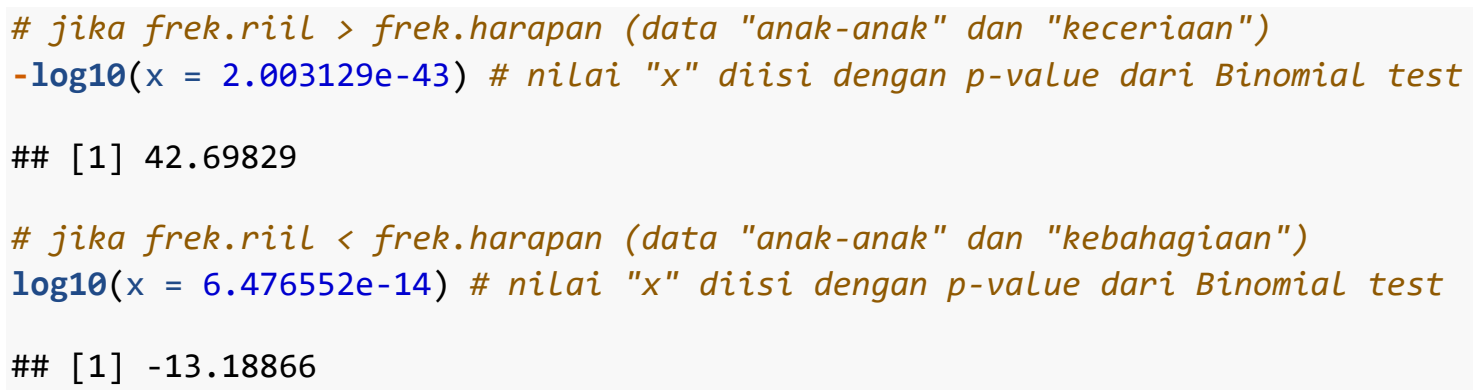

Hal yang perlu diperhatikan adalah derajat kekhasan ditunjukkan oleh nilai positif (42.698), sedangkan ketidakkhasan akan ditunjukkan oleh nilai daya asosiasi yang negatif (13.189). Semakin tinggi nilai daya asosiasi, semakin kuat asosiasi antara suatu kolokat dan sinonim. Sebaliknya, semakin rendahnya nilai daya asosiasi mengindikasikan lemahnya daya asosiasi (atau kuatnya daya ketertolakan [repulsion]) antara suatu kolokat dan sinonim.

Penghitungan uji binomial untuk MDCA di atas dilakukan untuk semua tipe kolokat yang muncul dengan sinonim yang dikaji; dalam hal ini, terdapat 7,290 tipe kolokat pada pangkalan data. Penghitungan manual satu per satu menjadi tidak efektif. Untuk itu, dirancang fungsi pemrograman $\mathrm{R}$ yang dapat secara otomatis melakukan MDCA untuk seluruh kolokat yang ada. Fungsi ini disebut mdca() dan tersedia secara terbuka, bersama dengan keseluruhan data, dalam modul R happyr (G. P. W. Rajeg, 2019c). Pemrosesan data dan analisis juga menggunakan fungsi-fungsi dalam gugusan modul R tidyverse (Wickham et al., 2019). Selanjutnya, tiap-tiap kolokat dapat diurutkan berdasarkan besaran daya asosiasi/kekhasannya terhadap tiap-tiap sinonim. Kemudian, daftar peringkat kolokat khas tersebut dapat menjadi titik tolak untuk membahas dan membandingkan pencirian semantis dari tiap-tiap sinonim KEBAHAGIAAN; tentunya intuisi semantis berperan penting dalam memberikan interpretasi kualitatif terhadap luaran kuantitatif dari MDCA. Bagian Hasil dan Pembahasan menampilkan hasil MDCA untuk sinonim yang merupakan bentuk turunan dengan nominalisasi ke-/-an (lihat bagian selanjutnya). 


\section{SUMBER DATA DAN METODOLOGI}

Sumber data utama makalah ini adalah sepuluh berkas dari Korpus Bahasa Indonesia Leipzig (Goldhahn et al., 2012; Quasthoff \& Goldhahn, 2013) (perhatikan Tabel 2). Total ukuran kesepuluh berkas korpus tersebut berjumlah 98,006,421 kata.

Tabel 2 Berkas dan Ukuran Korpus Leipzig Bahasa Indonesia yang Digunakan pada Makalah Ini

\begin{tabular}{llc}
\hline \hline No. & Nama Berkas Korpus & Ukuran (berdasarkan jumlah kata) \\
\hline 1 & ind_mixed_2012_1M-sentences.txt & $15,052,159$ \\
\hline 2 & ind_news_2008_300K-sentences.txt & $5,875,376$ \\
\hline 3 & ind_news_2009_300K-sentences.txt & $5,868,276$ \\
\hline 4 & ind_news_2010_300K-sentences.txt & $5,874,158$ \\
\hline 5 & ind_news_2011_300K-sentences.txt & $5,852,211$ \\
\hline 6 & ind_news_2012_300K-sentences.txt & $5,873,523$ \\
\hline 7 & ind_newscrawl_2011_1M-sentences.txt & $16,376,426$ \\
\hline 8 & ind_newscrawl_2012_1M-sentences.txt & $16,916,778$ \\
\hline 9 & ind_web_2011_300K-sentences.txt & $4,472,885$ \\
\hline 10 & ind_web_2012_1M-sentences.txt & $15,844,629$ \\
\hline \hline
\end{tabular}

Terdapat sepuluh leksikon KEBAHAGIAAN yang diikutkan dalam analisis kuantitatif (perhatikan Tabel 3). Lima di antaranya adalah bentuk akar yang telah dikelompokkan secara manual muncul dalam konteks sebagai nomina, bukan adjektiva atau predikat (lihat G. P. W. Rajeg, 2019a, hlm. 58-59, untuk ulasan lebih lanjut), yaitu senang, bahagia, riang, gembira, dan ceria. Alasan dipilihnya kelima bentuk akar ini didasari atas statusnya sebagai lima kata representatif teratas yang merujuk pada kategori KEBAHAGIAAN dalam bahasa Indonesia (temuan yang dilaporkan oleh Shaver dkk., 2001, hlm. 217). Lima kata lainnya adalah bentuk nominalisasi dari bentuk akar tadi, yaitu kesenangan, kebahagiaan, keriangan, kegembiraan, dan keceriaan. Meskipun kelima bentuk akar nominal diikutkan dalam analisis kuantitatif bersama dengan bentuk nominalisasi ke-/-an, bagian Hasil dan Pembahasan hanya akan menampilkan hasil dari bentuk nominalisasi ke-/-an, atas dasar rendahnya kemunculan bentuk akar dalam konteks nominal. Akan tetapi, hasil penuh analisis kuantitatif akan dibagikan secara terbuka untuk pembaca dapat periksa secara mandiri (lihat informasi lebih terperinci pada G. P. W. Rajeg, 2020). 
Tabel 3 Frekuensi Kemunculan Sinonim KEBAHAGIAAN di Korpus Leipzig Bahasa Indonesia

\begin{tabular}{|c|c|c|c|c|}
\hline No. & Pola Pencarian2 & Lesikon Target Pencarian & Bentuk Morfologis & $\mathbf{N}$ \\
\hline 1 & $\mathrm{lb}(? \mathrm{i})$ senang $\backslash \mathrm{b}$ & senang & akar & 14,531 \\
\hline 2 & $\mathrm{lb}(? \mathrm{i})$ bahagialb & bahagia & akar & 6,178 \\
\hline 3 & lb(?i)gembiralb & gembira & akar & 4,387 \\
\hline 4 & $\mathrm{lb}(? \mathrm{i})$ cerialb & ceria & akar & 880 \\
\hline 5 & $\mathrm{lb}(? \mathrm{i})$ riang $\backslash \mathrm{b}$ & riang & akar & 528 \\
\hline 6 & $\mathrm{lb}(? \mathrm{i}) \mathrm{kebahagiaan} \backslash \mathrm{b}$ & kebahagiaan & nominalisasi ke--an & 3,228 \\
\hline 7 & $\mathrm{lb}(? \mathrm{i})$ kesenangan $\mathrm{lb}$ & kesenangan & nominalisasi ke--an & 1,293 \\
\hline 8 & $\mathrm{lb}(? \mathrm{i})$ kegembiraan $\backslash \mathrm{b}$ & kegembiraan & nominalisasi ke--an & 1,211 \\
\hline 9 & $\mathrm{lb}(? \mathrm{i})$ keceriaan $\mathrm{lb}$ & keceriaan & nominalisasi ke--an & 265 \\
\hline 10 & $\mathrm{lb}($ ? $\mathrm{i})$ keriangan $\mathrm{lb}$ & keriangan & nominalisasi $k e--a n$ & 60 \\
\hline
\end{tabular}

Sumber data tambahan untuk keceriaan $(\mathrm{N}=265)$ dan keriangan $(\mathrm{N}=60)$, yang kemunculannya sangat rendah di korpus Leipzig, diperoleh dari Indonesian Web as Corpus pada Sketch Engine (SKE), dan sepuluh surat kabar daring Indonesia yang ditelusuri dengan WebCorp (lihat G. P. W. Rajeg, 2019a, hlm. 58-61 untuk pemaparan lebih lanjut terkait data).

Selanjutnya, yang menjadi data utama dalam mengkaji nuansa semantis sinonim KEBAHAGIAAN adalah kata-kata yang muncul dalam bingkai empat kata di sebelah kanan dan kiri (yaitu kolokat [collocates]) dari tiap-tiap sinonim di dalam kalimat (perhatikan Tabel 4). Kolokat tersebut merupakan bagian dari konteks pemakaian sinonim di dalam korpus. Kolokat yang merupakan kata-kata fungsional (disebut stopwords), seperti ada, adalah, agar, apalagi, bila, bisakah, dan, ini, jangan, karena, melainkan, tapi, untuk, dan yang, dipisahkan dan tidak diikutkan dalam analisis kuantitatif karena dipandang tidak memberikan kontribusi semantis substantif, mengingat frekuensi kemunculan mereka yang tinggi dan bisa muncul dengan banyak kata3. Sinonim target yang ditemukan menjadi kolokat dari sinonim target lainnya juga tidak diikutkan. Hal ini dilakukan untuk mengurangi pengaruh penyamaan semantis (semantic levelling) jika ingin mengetahui perbedaan semantis di antara sinonim yang dikaji (Gevaert, 2007, hlm. 197; G. P. W. Rajeg, 2019a, hlm. 61).

Tabel 4 menampilkan nukilan acak pangkalan data kolokat yang diolah dan diperoleh secara komputasional menggunakan R. Penjelasan untuk tiap-tiap kolom adalah sebagai berikut.

i. KOLOKAT: kolokat yang muncul di sekitar sinonim target dalam kalimat.

ii. SINONIM: sinonim target.

iii. RENTANG (SPAN): posisi linear dari suatu kolokat sehubungan dengan sinonim target di dalam kalimat. Angka menunjukkan urutan linear kolokat dari sinonim target. Contohnya, RENTANG -4 untuk kata cara (baris ketiga pada Tabel 4) menunjukkan bahwa cara ada di posisi kata keempat di sebelah kiri (sehingga ditandai negatif -) dari sinonim target. Sebaliknya, RENTANG dengan angka positif (baris terakhir, yaitu RENTANG 4) mengindikasikan posisi kolokat di sebelah kanan sinonim target (periksa kolom SITIRAN KALIMAT). 
iv. BERKAS KORPUS: nama berkas korpus kemunculan kolokat dan sinonim.

v. NO. BARIS KALIMAT: baris kalimat tempat ditemukannya kemunculan suatu kolokat dengan sinonim.

vi. SITIRAN KALIMAT: sitiran kalimat penuh kemunculan suatu kolokat dengan sinonim. Tiap-tiap kolokat diberi tanda $(\mathrm{tag})<$ colloc $\operatorname{span}=\ldots></$ colloc $>$ dengan informasi rentangnya (yaitu span), sedangkan sinonim target juga ditandai dengan $<$ node $></$ node $>$ mengindikasikan peran sinonim sebagai kata kunci/pusat. 


\begin{tabular}{|c|c|c|c|c|c|}
\hline KOLOKAT & SINONIM & RENTANG & BERKAS KORPUS & NO. BARIS KALIMAT & SITIRAN KALIMAT \\
\hline putung & kegembiraan & -4 & corp_iWeb2011_300K & 228279 & $\begin{array}{l}\text { sinarnya yang berwarna kuning cerah menyiram kademangan sangkal } \\
<\text { colloc span }=-4>\text { putung }</ \text { colloc }>\text { seolah-olah sengaja menyiramkan } \\
<\text { node }>\text { kegembiraan }</ \text { node }>\text { bagi para penghuninya }\end{array}$ \\
\hline membawa & kebahagiaan & -1 & corp_iMxd2012_1M & 158250 & $\begin{array}{l}\text { karena kesepian ibu akhirnya berteman dengan sesuatu yang }<\text { colloc } \\
\text { span }=-1>\text { membawa }</ \text { colloc }><\text { node }>\text { kebahagiaan }</ \text { node }>\text { semu baginya }\end{array}$ \\
\hline cara & kebahagiaan & -4 & corp_iWeb2012_1M & 260603 & $\begin{array}{l}\text { begitulah }<\text { colloc span }=-4>\text { cara }</ \text { colloc }>\text { domba saya mengalami } \\
<\text { node }>\text { kebahagiaan }</ \text { node }>\end{array}$ \\
\hline baik & kebahagiaan & -3 & corp_iWeb2011_300K & 83418 & $\begin{array}{l}\text { berbagai celah kesempatan senantiasa terbuka bagi setiap insan untuk } \\
\text { mengambil manfaat dan hikmah yang terkandung di dalamnya }<\text { colloc } \\
\text { span }=-3>\text { baik }</ \text { colloc }>\text { itu dalam }<\text { node }>\text { kebahagiaan }</ \text { node }>\text { maupun } \\
\text { penderitan }\end{array}$ \\
\hline baru & kebahagiaan & -3 & corp_iNwsCrw2012_1M & 190052 & $\begin{array}{l}\text { ia mengajak warga tionghoa dan masyarakat lainnya di kota pontianak } \\
\text { untuk memulai hidup }<\text { colloc span }=-3>\text { baru }</ \text { colloc }>\text { dengan penuh } \\
<\text { node }>\text { kebahagiaan }</ \text { node }>\text { atau disebut gong xi fat chai }\end{array}$ \\
\hline tenggelam & kebahagiaan & -2 & corp_iNews2010_300K & 69822 & $\begin{array}{l}\text { kami }<\text { colloc span }=-2>\text { tenggelam }</ \text { colloc }>\text { dalam } \\
<\text { node }>\text { kebahagiaan }</ \text { node }>\text { dan kegembiraan pada saat yang sangat } \\
\text { istimewa ini kata pasangan tersebut kepada us weekly }\end{array}$ \\
\hline menulis & kegembiraan & -4 & corp_iNews2009_300K & 46433 & $\begin{array}{l}\text { ia }<\text { colloc span }=-4>\text { menulis }</ \text { colloc }>\text { semangat saat ini } \\
<\text { node }>\text { kegembiraan }</ \text { node }>\text { yang luar biasa }\end{array}$ \\
\hline dan & keriangan & -1 & riang_SKE & 48_refID_73753_riang & $\begin{array}{l}\text { ketulusan }<\text { colloc span }=-1>\text { dan }</ \text { colloc }><\text { node }>\text { keriangan }</ \text { node }>\text { hati } \\
\text { inilah yang akan membuat film ini akan mendapat perhatian penonton }\end{array}$ \\
\hline lebih-lebih & kebahagiaan & -1 & corp_iWeb2012_1M & 216429 & $\begin{array}{l}\text { namun rumah tangga yang bisa membawa kita kepada kebahagiaan hidup } \\
\text { di dunia }<\text { colloc span }=-1>\text { lebih-lebih }</ \text { colloc }> \\
\langle\text { node }>\text { kebahagiaan }</ \text { node }>\text { di akhirat }\end{array}$ \\
\hline dan & kebahagiaan & 4 & corp_iMxd2012_1M & 172770 & $\begin{array}{l}\text { di mata jaja jelas terpancar kegembiraan dan }\langle\text { node }>\text { kebahagiaan }</ \text { node }> \\
\text { bila bersama kau }<\text { colloc } \text { span }=4>\text { dan }</ \text { colloc }>\text { kami }\end{array}$ \\
\hline
\end{tabular}

Tabel 4 Nukilan Acak Pangkalan Data Kolokat Sinonim KEBAHAgIAAN (khususnya bentuk nominalisasi ke-/-an) 
Frekuensi kemunculan tiap-tiap sinonim dengan kolokat tersisa yang relevan kemudian menjadi masukan MDCA, yang telah diulas secara rinci sebelumnya. MDCA akan menentukan kata mana yang secara kuat dan khas berkolokasi dengan satu sinonim jika dibandingkan dengan sinonim lainnya. Semakin tinggi nilai kekhasan atau daya asosiasi antara suatu kolokat, semakin khas kolokat tersebut dikaitkan dengan sinonim yang dikaji (lihat Tabel 1). Dalam CollAna, ambang batas terendah untuk daya asosiasi atau nilai kekhasan yang signifikan (sebelum dikoreksi menggunakan metode Holm atau Bonferroni (Gries, 2009, hlm. 242-243) adalah AssocStr $=1.30103$ (atau setara dengan $p$ binomial $<0.05$ ). Ambang batas yang lebih tinggi dapat diterapkan, yaitu AssocStr $=2$ (setara dengan pbinomial $<0.01)$ dan AssocStr $=3$ (setara dengan $p$ binomial $<0.001$ ) (lihat Stefanowitsch \& Gries, 2005, hlm. 7). Koreksi pbinomial-value dengan metode Holm4 akan tetap ditampilkan pada pembahasan, mengikuti Stefanowitsch (2011, hlm. 282, Tabel 12), meskipun fokus utama CollAna adalah pemeringkatan kolokat berdasarkan nilai AssocStr, bukannya putusan signifikansi statistik secara ketat (untuk ulasan lebih lanjut, lihat Stefanowitsch \& Gries, 2005, hlm. 36, catatan akhir no. 3, 2003, hlm. 239, catatan akhir no. 6, dan, 2009, hlm. 944).

Daftar kolokat khas yang dihasilkan untuk tiap-tiap sinonim kemudian diulas secara kualitatif guna mencirikan makna, pemakaian, serta konsep-konsep yang berkaitan khas dengan sinonim tersebut, dan membandingkannya dengan sinonim yang lain. Salah satu ulasan utamanya adalah menampilkan frekuensi dari pola nyata konstruksi pemakaian kolokat tersebut dengan salah satu kata kebahagiaan, pola yang diekstrak dari sitiran kalimat tempat kedua kata tersebut muncul. Dengan demikian, hubungan antara kolokat dan sinonim dapat dipahami dalam konteks konstruksi pemakaiannya.

\section{HASIL DAN PEMBAHASAN}

Bagian ini menampilkan hasil analisis kolokat khas dengan MDCA untuk sinonim KEBAHAGIAAN dalam bahasa Indonesia. Analisis ini bertujuan untuk memberikan landasan empiris, berdasarkan data pemakaian bahasa dan metode LKorp kuantitatif, terkait salah satu asumsi teoretis yang diajukan oleh Kövecses (1990) mengenai konsep terkait yang mencirikan makna suatu konsep emosi (lihat juga Kövecses, 2015, hlm. 158). MDCA memungkinkan peneliti untuk menemukenali konsep-konsep terkait dari suatu emosi berdasarkan kolokat khasnya (misalnya: kolokat nomina yang mengacu pada (i) konsep perasaan/emosi lain, (ii) sikap, atau (iii) kejadian), dan kemudian membandingkannya dengan emosi yang mirip secara semantis. Menurut pandangan UBL, perbedaan pilihan kolokasi dari suatu kata dibandingkan dengan sinonimnya mengindikasikan perbedaan semantis kata-kata sinonim tersebut (Hilpert, 2006, hlm. 243). Di sisi lain, bagian ini akan menunjukkan pula bahwa lingkup empat kata di sebelah kiri dan kanan dari sinonim juga dapat menangkap kolokat yang mengindikasikan pemakaian metaforis dari sinonim tersebut, meskipun metafora tidak menjadi fokus utama makalah ini.

\section{Kolokat Khas untuk Kebahagiaan}

Tabel 5 menampilkan 20 kolokat khas teratas untuk KEBAHAGIAAN (diurutkan berdasarkan nilai pada kolom assocstr). Kolokat tersebut secara signifikan muncul lebih sering dari yang diharapkan dengan kebahagiaan dalam korpus penelitian ini. Kolom signif mengindikasikan tingkat signifikansi $p$-value yang dikoreksi dengan metode Holm, yaitu $* * *=p$ Holm $<0.001$; $* *$ $=p$ Holm $<0.01 ; *=p$ Holm $<0.05 ; \mathrm{ms}=$ marginally significant $; \mathrm{ns}=$ not significant . 
Tabel 5 Daftar 20 Kolokat Khas Teratas untuk Kebahagiaan di Korpus Leipzig Bahasa Indonesia

\begin{tabular}{llrrrrrl}
\hline \hline No. & Kolokat & $\mathbf{N}$ & $\mathbf{e x p}$ & assocstr & p_binomial & p_holm & signif \\
\hline \hline 1 & kesejahteraan & 82 & 32.701 & 29.646 & $2.258 \mathrm{e}-30$ & $1.646 \mathrm{e}-25$ & $* * *$ \\
\hline 2 & sejati & 89 & 37.703 & 26.595 & $2.538 \mathrm{e}-27$ & $1.850 \mathrm{e}-22$ & $* * *$ \\
\hline 3 & mencapai & 87 & 42.704 & 16.944 & $1.136 \mathrm{e}-17$ & $8.282 \mathrm{e}-13$ & $* * *$ \\
\hline 4 & akhirat & 66 & 29.624 & 16.829 & $1.482 \mathrm{e}-17$ & $1.080 \mathrm{e}-12$ & $* * *$ \\
\hline 5 & kesuksesan & 42 & 18.467 & 11.562 & $2.745 \mathrm{e}-12$ & $2.000 \mathrm{e}-07$ & $* * *$ \\
\hline 6 & kedamaian & 56 & 27.315 & 11.358 & $4.389 \mathrm{e}-12$ & $3.198 \mathrm{e}-07$ & $* * *$ \\
\hline 7 & menemukan & 68 & 35.394 & 11.260 & $5.496 \mathrm{e}-12$ & $4.005 \mathrm{e}-07$ & $* * *$ \\
\hline 8 & manusia & 87 & 50.399 & 10.034 & $9.257 \mathrm{e}-11$ & $6.745 \mathrm{e}-06$ & $* * *$ \\
\hline 9 & hidup & 172 & 116.956 & 9.889 & $1.290 \mathrm{e}-10$ & $9.401 \mathrm{e}-06$ & $* * *$ \\
\hline 10 & abadi & 49 & 24.238 & 9.626 & $2.365 \mathrm{e}-10$ & $1.723 \mathrm{e}-05$ & $* * *$ \\
\hline 11 & tangga & 37 & 16.928 & 9.191 & $6.447 \mathrm{e}-10$ & $4.697 \mathrm{e}-05$ & $* * *$ \\
\hline 12 & menuju & 45 & 22.314 & 8.829 & $1.483 \mathrm{e}-09$ & $1.081 \mathrm{e}-04$ & $* * *$ \\
\hline 13 & hakiki & 26 & 10.772 & 8.610 & $2.452 \mathrm{e}-09$ & $1.786 \mathrm{e}-04$ & $* * *$ \\
\hline 14 & dunia & 132 & 88.486 & 8.302 & $4.992 \mathrm{e}-09$ & $3.637 \mathrm{e}-04$ & $* * *$ \\
\hline 15 & keselamatan & 32 & 14.619 & 8.049 & $8.939 \mathrm{e}-09$ & $6.512 \mathrm{e}-04$ & $* * *$ \\
\hline 16 & kesehatan & 35 & 16.543 & 7.982 & $1.041 \mathrm{e}-08$ & $7.584 \mathrm{e}-04$ & $* * *$ \\
\hline 17 & meraih & 45 & 23.853 & 7.274 & $5.322 \mathrm{e}-08$ & $3.876 \mathrm{e}-03$ & $* *$ \\
\hline 18 & umat & 26 & 11.542 & 7.151 & $7.063 \mathrm{e}-08$ & $5.144 \mathrm{e}-03$ & $* *$ \\
\hline 19 & orang & 120 & 82.331 & 6.855 & $1.396 \mathrm{e}-07$ & $1.016 \mathrm{e}-02$ & $*$ \\
\hline 20 & merasakan & 92 & 60.017 & 6.752 & $1.769 \mathrm{e}-07$ & $1.288 \mathrm{e}-02$ & $*$ \\
\hline \hline & & & & & & & \\
\hline
\end{tabular}

Sebagian besar dari 20 kolokat khas tersebut mengindikasikan rentang semantis bernuansa positif untuk kebahagiaan. Sejumlah subtema semantis dapat diajukan. Kata abadi dan akhirat mengindikasikan sifat kekekalan dari kebahagiaan, yang tidak dimiliki oleh kesenangan (lihat Tabel 6). Abadi paling sering muncul sebagai penjelas dalam konstruksi modifikasi, seperti kebahagiaan abadi $(\mathrm{N}=27$ sitiran), kebahagiaan yang (hakiki dan) abadi $(\mathrm{N}=8)$, kebahagiaan dan kesengsaraan/kemuliaan nan abadi $(\mathrm{N}=3)$, kebahagiaan hidup/spiritual (yang) abadi $(\mathrm{N}=2$ ). Akhirat juga muncul sebagai penjelas bagi kebahagiaan, contohnya kebahagiaan (dunia dan) akhirat $(\mathrm{N}=28)$; kebahagiaan dunia akhirat $(\mathrm{N}=4)$, kebahagiaan di dunia dan akhirat $(\mathrm{N}=7)$, kebahagiaan di akhirat $(\mathrm{N}=7)$. Selanjutnya, kata hakiki dan sejati mencirikan sifat keaslian dari kebahagiaan. Kedua kolokat ini paling sering muncul dalam konstruksi modifikasi: kebahagiaan (yang) hakiki $(\mathrm{N}=21)$ dan kebahagiaan (yang) sejati $(\mathrm{N}=76)$.

Berbeda dengan pandangan yang ditunjukkan oleh konstruksi dengan akhirat, keberadaan dunia (baris 14) sebagai kolokat khas mengindikasikan bahwa kebahagiaan dapat juga dirasakan di dunia. Dunia muncul dalam konstruksi modifikasi dengan kebahagiaan sebagai inti, misalnya kebahagiaan dunia $(\mathrm{N}=33)$; kebahagiaan di dunia $(\mathrm{N}=32)$; kebahagiaan hidup di dunia $(\mathrm{N}=11)$; kebahagiaan hidup dunia $(\mathrm{N}=3)$. Orang, manusia, dan 
umat dapat mengindikasikan bahwa kebahagiaan merupakan khasanah ataupun mungkin tujuan bagi orang banyak. Berikut beberapa contoh pola kolokasi yang paling tinggi kekerapannya untuk orang, manusia, dan umat: kebahagiaan orang $(\mathrm{N}=33)$, kebahagiaan bagi (semua)/dengan/kepada/pada/sebagai orang $(\mathrm{N}=15)$; kebahagiaan manusia $(\mathrm{N}=17)$, kebahagiaan (bagi) umat manusia $(\mathrm{N}=8)$, manusia untuk mencapai kebahagiaan $(\mathrm{N}=5)$; kebahagiaan (bagi) umat $(\mathrm{N}=11)$, kebahagiaan dan kesejahteraan umat $(\mathrm{N}=2)$.

Kemudian, kolokat khas lainnya dalam bentuk nominalisasi ke-/-an menunjukkan kaitan antara kebahagiaan dengan konsep-konsep positif dambaan terkait kemakmuran: kesejahteraan (kolokat khas terkuat), kesuksesan, kedamaian, keselamatan, dan kesehatan. Hal yang menarik adalah kolokat khas kategori kemakmuran tersebut tampak sejalan dengan batasan makna untuk kebahagiaan dalam Kamus Besar Bahasa Indonesia (KBBI) Daring (https://kbbi.kemdikbud.go.id/entri/kebahagiaan): 'kesenangan dan ketenteraman hidup (lahir batin); keberuntungan'. Hal ini menunjukkan bagaimana hasil berdasarkan data dan metode empiris seperti LKorp dan UBL dapat selaras dengan makna kata dalam kamus.

Seperti disebutkan di awal bagian ini, terdapat sejumlah kolokat, khususnya verba, yang mengindikasikan pola metaforis linguistik untuk kebahagiaan. Verba yang dimaksud adalah mencapai, menemukan, menuju, dan meraih. Konstruksi kolokasi lazim/yang paling sering muncul adalah konstruksi transitif, dengan kebahagiaan mengisi slot objek langsung verba tersebut: menuju kebahagiaan $(\mathrm{N}=47)$, menuju keindahan dan kebahagiaan $(\mathrm{N}=4)$; mencapai kebahagiaan $(\mathrm{N}=68)$, mencapai puncak/taraf kebahagiaan $(\mathrm{N}=4)$; menemukan kebahagiaan $(\mathrm{N}=53)$, menemukan kepuasan, kedamaian, kebahagiaan $(\mathrm{N}=2)$; meraih kebahagiaan $(\mathrm{N}=$ 38). Pola kolokasi metaforis tersebut mencerminkan konseptualisasi metaforis (lihat Lakoff \& Johnson, 1980, 1999; Lakoff, 1993) bahwa kebahagiaan dipahami sebagai suatu destinasi, tujuan akhir, atau objek yang didambakan. Metafora konseptual ini, yang mencerminkan metafora model PENCARIAN (the PURSUIT model) (lihat Stefanowitsch, 2004, 2006), khas berasosiasi dengan kata kebahagiaan (periksa G. P. W. Rajeg, 2019a, hlm. 219; I. M. Rajeg, 2013) dan juga kata happiness dalam bahasa Inggris (Stefanowitsch, 2004, 2006). Temuan ini menunjukkan bahwa ekuivalensi kata dalam ranah emosi lintas bahasa dapat ditemukan melalui kemiripan profil semantis/metaforis kata-kata tersebut berdasarkan atas kajian empiris melalui UBL dan LKorp.

\section{Kolokat Khas untuk Kesenangan}

Tabel 6 menampilkan 20 kolokat khas teratas yang berasosiasi kuat dengan kesenangan. Beberapa kolokat khas berikut mengangkat nuansa semantis berbeda yang dimiliki oleh kesenangan jika dibandingkan dengan kebahagiaan sebelumnya (dan dengan sinonim lainnya).

Tabel 6 Daftar 20 Kolokat Khas Teratas untuk kesenangan di Korpus Leipzig Bahasa Indonesia

\begin{tabular}{llrrrlll}
\hline \hline No. & Kolokat & N & exp & assocstr & p_binomial & p_holm & signif \\
\hline 1 & duniawi & 52 & 10.298 & 28.818 & $1.520 \mathrm{e}-29$ & $1.108 \mathrm{e}-24$ & $* * *$ \\
\hline 2 & pribadi & 30 & 5.994 & 16.702 & $1.985 \mathrm{e}-17$ & $1.446 \mathrm{e}-12$ & $* * *$ \\
\hline 3 & mencari & 55 & 17.522 & 15.757 & $1.748 \mathrm{e}-16$ & $1.274 \mathrm{e}-11$ & $* * *$ \\
\hline 4 & kenikmatan & 37 & 11.835 & 10.789 & $1.624 \mathrm{e}-11$ & $1.184 \mathrm{e}-06$ & $* * *$ \\
\hline 5 & hobi & 14 & 2.306 & 10.278 & $5.277 \mathrm{e}-11$ & $3.845 \mathrm{e}-06$ & $* * *$ \\
\hline
\end{tabular}




\begin{tabular}{llrrrrrl}
\hline \hline No. & Kolokat & $\mathbf{N}$ & exp & assocstr & p_binomial & p_holm & signif \\
\hline 6 & nafsu & 19 & 3.996 & 10.114 & $7.689 \mathrm{e}-11$ & $5.603 \mathrm{e}-06$ & $* * *$ \\
\hline 7 & semata & 14 & 2.613 & 8.756 & $1.756 \mathrm{e}-09$ & $1.279 \mathrm{e}-04$ & $* * *$ \\
\hline 8 & keuntungan & 12 & 2.152 & 7.934 & $1.165 \mathrm{e}-08$ & $8.488 \mathrm{e}-04$ & $* * *$ \\
\hline 9 & kepentingan & 13 & 2.613 & 7.464 & $3.438 \mathrm{e}-08$ & $2.504 \mathrm{e}-03$ & $* *$ \\
\hline 10 & seksual & 10 & 1.691 & 7.157 & $6.964 \mathrm{e}-08$ & $5.072 \mathrm{e}-03$ & $* *$ \\
\hline 11 & menikmati & 42 & 18.291 & 7.136 & $7.312 \mathrm{e}-08$ & $5.326 \mathrm{e}-03$ & $* *$ \\
\hline 12 & menunda & 8 & 1.230 & 6.507 & $3.115 \mathrm{e}-07$ & $2.268 \mathrm{e}-02$ & $*$ \\
\hline 13 & kebutuhan & 10 & 1.998 & 5.873 & $1.341 \mathrm{e}-06$ & $9.762 \mathrm{e}-02$ & $\mathrm{~ms}$ \\
\hline 14 & mengejar & 17 & 5.072 & 5.844 & $1.431 \mathrm{e}-06$ & $1.042 \mathrm{e}-01$ & $\mathrm{~ns}$ \\
\hline 15 & prinsip & 8 & 1.383 & 5.616 & $2.421 \mathrm{e}-06$ & $1.762 \mathrm{e}-01$ & $\mathrm{~ns}$ \\
\hline 16 & mendapat & 22 & 7.993 & 5.521 & $3.016 \mathrm{e}-06$ & $2.196 \mathrm{e}-01$ & $\mathrm{~ns}$ \\
\hline 17 & berdasarkan & 10 & 2.152 & 5.394 & $4.040 \mathrm{e}-06$ & $2.941 \mathrm{e}-01$ & $\mathrm{~ns}$ \\
\hline 18 & hawa & 9 & 1.844 & 5.171 & $6.744 \mathrm{e}-06$ & $4.908 \mathrm{e}-01$ & $\mathrm{~ns}$ \\
\hline 19 & waktu & 18 & 6.302 & 4.896 & $1.270 \mathrm{e}-05$ & $9.242 \mathrm{e}-01$ & $\mathrm{~ns}$ \\
\hline 20 & dosa & 6 & 0.922 & 4.880 & $1.319 \mathrm{e}-05$ & $9.594 \mathrm{e}-01$ & $\mathrm{~ns}$ \\
\hline \hline
\end{tabular}

Salah satu karakter semantis menonjol untuk kesenangan yang menarik untuk diulas adalah keterkaitannya dengan hal-hal keduniawian dan fana. Argumen ini dilandasi atas kolokat terkuat, yaitu duniawi, diikuti oleh nafsu, seksual, hawa, dan dosa. Karakter semantis kesenangan ini berbeda dengan kebahagiaan yang dominan menonjolkan kekekalan dan konsep-konsep positif ideal lainnya (misalnya: kesejahteraan). Sebelum menampilkan pola pemakaian kolokat tersebut, terdapat sedikit catatan untuk kata hawa, yang merupakan bagian dari konstruksi kata majemuk hawa nafsu. Delapan dari sembilan kemunculan hawa sebagai kolokat dalam rentang empat kata sebelah kanan dan kiri dari kesenangan menunjukkan hawa muncul dalam kata majemuk hawa nafsu; hanya pada satu sitiran tersisa hawa muncul sendiri dalam arti 'wanita' (lawan dari Adam).

Pola konstruksi lazim kemunculan duniawi dengan kesenangan adalah konstruksi modifikasi kesenangan duniawi $(\mathrm{N}=43)$, diikuti oleh kesenangan hidup duniawi $(\mathrm{N}=2)$. Pola lainnya, yang hanya muncul masing-masing sekali, adalah kesenangan fisik dan duniawi, kesenangan mewakili kebutuhan duniawi, dan kesenangan terhadap hal-hal duniawi. Untuk $n a f s u$, konstruksi kemunculannya cukup beragam, yang di antaranya bisa bersifat (i) modifikatif (kesenangan hawa nafsu $[\mathrm{N}=3]$, kesenangan nafsu $[\mathrm{N}=2]$ ) dan (ii) koordinatif (nafsu dan kesenangan $[\mathrm{N}=4]$, kesenangan dan nafsu $[\mathrm{N}=2]$ ). Konstruksi lainnya yang masing-masing muncul sekali bersifat predikatif-ekuatif, menyamakan kesenangan dengan nafsu: nafsu merupakan kesenangan, nafsu cenderung pada kesenangan, nafsu kamacchanda yaitu kesenangan, kesenangan atau dapat disebut nafsu (periksa $\mathrm{R}$ Notebook makalah ini untuk data lebih lengkap). Berikutnya, seksual berkolokasi dengan kesenangan paling sering dalam konstruksi modifikasi kesenangan seksual $(\mathrm{N}=6)$, kemudian kesenangan dan nafsu seksual dan kesenangan organ seksual yang masing-masing muncul satu kali. Pola kolokasi kesenangan dengan dosa mengindikasikan bahwa kesenangan bisa dilandasi atas dosa: kesenangan dari dosa $(\mathrm{N}=3)$, kesenangan dosa $(\mathrm{N}=2)$, dan kesenangan atas dosa $(\mathrm{N}=1)$. 
Konsep-konsep fana lainnya dapat ditunjukkan oleh kenikmatan, keuntungan, kebutuhan, kepentingan, dan hobi. Umumnya kesenangan muncul dengan kolokat tersebut dalam konstruksi koordinatif: kesenangan dan kenikmatan $(\mathrm{N}=16)$, kenikmatan dan kesenangan $(\mathrm{N}=7)$, kesenangan atau kenikmatan $(\mathrm{N}=2)$, kenikmatan atau kesenangan $(\mathrm{N}=$ $2)$; keuntungan dan kesenangan $(\mathrm{N}=3)$, kesenangan dan keuntungan $(\mathrm{N}=2)$, keuntungan materi dan kesenangan $(\mathrm{N}=1)$; kepentingan dan kesenangan $(\mathrm{N}=4)$, kesenangan dan kepentingan $(\mathrm{N}=4)$, kepentingan materi dan kesenangan $(\mathrm{N}=2)$; hobi atau kesenangan $(\mathrm{N}=$ $3)$, hobi dan kesenangan $(\mathrm{N}=3)$.

Kuatnya pribadi berkolokasi dengan kesenangan juga mengindikasikan nuansa makna berbeda di antara kesenangan dan kebahagiaan. Lingkup dari kesenangan lebih sempit karena berpusat pada diri sendiri (kesenangan pribadi $[\mathrm{N}=19]$, kesenangan atau minat pribadi $[\mathrm{N}=$ 2], kesenangan dan kepentingan-kepentingan pribadi $[\mathrm{N}=1]$, kesenangan diri pribadi $[\mathrm{N}=1]$ ). Di sisi lain, lingkup kebahagiaan lebih luas dan umum karena tampak merupakan suatu ideal bagi khalayak luas (ditunjukkan oleh kolokat khas manusia, orang, umat).

Terakhir, sejumlah kolokat khas verbal, seperti mencari, mengejar, dan mendapat membentuk model metaforis yang serupa antara kebahagiaan dan kesenangan. Kedua konsep ini dipahami sebagai suatu DESTINASI (LOKASI ataupun OBJEK) yang manusia ingin peroleh. Hasrat tersebut dipahami secara metaforis melalui ranah badaniah PERGERAKAN yang dipicu oleh mencari dan mengejar. Kata mengejar khususnya mencerminkan bahwa kesenangan sebagai suatu perasaan yang mesti segera terwujud (lihat G. P. W. Rajeg, 2019a, hlm. 220-221, 228, 2019b, hlm. 39-40 untuk ulasan lebih lanjut). Selanjutnya, penulis akan tunjukkan bahwa profil semantis dari kebahagiaan dan kesenangan berbeda dengan tiga sinonim tersisa lainnya.

\section{Kolokat Khas untuk Kegembiraan}

Berbeda dengan kebahagiaan dan kesenangan, sejumlah kolokat khas teratas untuk kegembiraan (lihat Tabel 7) terpusat pada ranah dan situasi munculnya kegembiraan beserta intensitasnya. Aspek intensitas ini utamanya tidak begitu ditonjolkan oleh kolokat khas untuk kebahagiaan dan kesenangan.

Tabel 7 Daftar 20 Kolokat Khas Teratas untuk kegembiraan di Korpus Leipzig Bahasa Indonesia

\begin{tabular}{llrrrrrl}
\hline \hline No. & Kolokat & N & exp & assocstr & p_binomial & p_holm & signif \\
\hline 1 & luapan & 24 & 4.756 & 13.603 & $2.494 \mathrm{e}-14$ & $1.818 \mathrm{e}-09$ & $* * *$ \\
\hline 2 & meluapkan & 21 & 3.835 & 13.269 & $5.377 \mathrm{e}-14$ & $3.919 \mathrm{e}-09$ & $* * *$ \\
\hline 3 & menyatakan & 17 & 4.142 & 7.592 & $2.559 \mathrm{e}-08$ & $1.864 \mathrm{e}-03$ & $* *$ \\
\hline 4 & pendukung & 15 & 3.682 & 6.701 & $1.993 \mathrm{e}-07$ & $1.451 \mathrm{e}-02$ & $*$ \\
\hline 5 & menyambut & 21 & 6.904 & 6.162 & $6.883 \mathrm{e}-07$ & $5.011 \mathrm{e}-02$ & $\mathrm{~ms}$ \\
\hline 6 & larut & 14 & 3.682 & 5.774 & $1.683 \mathrm{e}-06$ & $1.225 \mathrm{e}-01$ & $\mathrm{~ns}$ \\
\hline 7 & kesedihan & 19 & 6.597 & 5.197 & $6.351 \mathrm{e}-06$ & $4.622 \mathrm{e}-01$ & $\mathrm{~ns}$ \\
\hline 8 & terlihat & 22 & 8.591 & 4.907 & $1.238 \mathrm{e}-05$ & $9.007 \mathrm{e}-01$ & $\mathrm{~ns}$ \\
\hline 9 & menyaksikan & 10 & 2.455 & 4.628 & $2.357 \mathrm{e}-05$ & $1.000 \mathrm{e}+00$ & $\mathrm{~ns}$ \\
\hline 10 & masyarakat & 25 & 11.046 & 4.402 & $3.963 \mathrm{e}-05$ & $1.000 \mathrm{e}+00$ & $\mathrm{~ns}$ \\
\hline 11 & kubu & 7 & 1.381 & 4.268 & $5.400 \mathrm{e}-05$ & $1.000 \mathrm{e}+00$ & $\mathrm{~ns}$ \\
\hline
\end{tabular}




\begin{tabular}{llrrrlll}
\hline \hline No. & Kolokat & N & exp & assocstr & p_binomial & p_holm & signif \\
\hline 12 & warga & 16 & 5.830 & 4.158 & $6.955 \mathrm{e}-05$ & $1.000 \mathrm{e}+00$ & $\mathrm{~ns}$ \\
\hline 13 & gol & 5 & 0.767 & 4.071 & $8.499 \mathrm{e}-05$ & $1.000 \mathrm{e}+00$ & $\mathrm{~ns}$ \\
\hline 14 & tim & 12 & 3.835 & 3.910 & $1.231 \mathrm{e}-04$ & $1.000 \mathrm{e}+00$ & $\mathrm{~ns}$ \\
\hline 15 & dirasakan & 22 & 9.819 & 3.875 & $1.333 \mathrm{e}-04$ & $1.000 \mathrm{e}+00$ & $\mathrm{~ns}$ \\
\hline 16 & paskah & 6 & 1.227 & 3.560 & $2.755 \mathrm{e}-04$ & $1.000 \mathrm{e}+00$ & $\mathrm{~ns}$ \\
\hline 17 & pemain & 10 & 3.068 & 3.522 & $3.003 \mathrm{e}-04$ & $1.000 \mathrm{e}+00$ & $\mathrm{~ns}$ \\
\hline 18 & laga & 5 & 0.921 & 3.352 & $4.448 \mathrm{e}-04$ & $1.000 \mathrm{e}+00$ & $\mathrm{~ns}$ \\
\hline 19 & belanda & 4 & 0.614 & 3.257 & $5.540 \mathrm{e}-04$ & $1.000 \mathrm{e}+00$ & $\mathrm{~ns}$ \\
\hline 20 & dihati & 4 & 0.614 & 3.257 & $5.540 \mathrm{e}-04$ & $1.000 \mathrm{e}+00$ & $\mathrm{~ns}$ \\
\hline 21 & gawang & 4 & 0.614 & 3.257 & $5.540 \mathrm{e}-04$ & $1.000 \mathrm{e}+00$ & $\mathrm{~ns}$ \\
\hline \hline
\end{tabular}

Ranah atau situasi yang dominan berasosiasi dengan perasaan bernama kegembiraan adalah ranah KOMPETISI, khususnya OLAHRAGA. Ranah ini tercermin pada kolokat seperti pendukung, kubu, gol, tim, pemain, laga, Belanda, dan gawang. Tipe semantis yang diungkap kolokat ini dapat (i) dipandang sebagai ranah pemicu perasaan kegembiraan dan, (ii) beberapa di antaranya (misalnya: tim, pendukung, dan $k u b u$ ), mengindikasikan ciri kolektif dari kegembiraan (jika dibandingkan dengan ciri privasi yang dimiliki oleh kesenangan atau ciri umum dari kebahagiaan). Ciri kolektif dan sosial dari kegembiraan juga tecermin pada tiga kolokat lainnya, yaitu warga, masyarakat, dan paskah.

Dominasi kolokat khas dari ranah KOMPETISI selaras dengan kolokat khas lainnya yang mengungkapkan intensitas kegembiraan secara metaforis. Kolokat khas terkuat, yaitu luapan (luapan [ekspresi] kegembiraan [ $\mathrm{N}=24]$ ), diikuti oleh meluapkan (meluapkan [rasa/ekspresi] kegembiraan $[\mathrm{N}=21]$ ), menunjukkan tingginya intensitas perasaan yang ditimbulkan oleh kegembiraan. Ciri ini tidak ditonjolkan oleh kolokat khas dari kebahagiaan maupun kesenangan. Konstruksi metaforis dengan luapan dan meluapkan menunjukkan bahwa kegembiraan dipahami secara metaforis sebagai suatu cairan (KEGEMBIRAAN ADALAH CAIRAN DALAM WADAH (G. P. W. Rajeg, 2019a, hlm. 235-237)); berlebihnya jumlah cairan yang ada atau dipanaskannya cairan dalam wadah (seperti meluapkan) mengindikasikan peningkatan intensitas perasaan yang dialami. Satu kolokat lain yang muncul dalam konstruksi metaforis dan yang mengindikasikan intensitas kegembiraan adalah larut (larut dalam kegembiraan [ $\mathrm{N}=13$ ], larut dengan kegembiraan [N = 1]) (lihat G. P. W. Rajeg, 2019a, hlm. 238). Konstruksi dengan larut mengindikasikan ketidakberdayaan dan kepasifan si pengalam saat merasakan kegembiraan yang intens (yang digambarkan layaknya terlarut dalam cairan yang kuat).

Yang menarik adalah ranah KOMPETISI ataupun kegiatan sosial seperti paskah menjadi konteks yang memungkinkan bagi suatu perasaan mencapai intensitas dan euforia yang tinggi sehingga membuat pengalamnya terlena. Selain unsur intensitas, ranah KOMPETISI seperti OLAHRAGA juga memungkinkan untuk munculnya ciri lain dari kegembiraan yang berkaitan dengan suasana euforia, yaitu ciri ekspresif. Hal ini dilandasi atas kolokat khas seperti menyatakan, terlihat, dan menyaksikan, khususnya dalam konstruksi struktur-argumen sebagai berikut: menyatakan kegembiraan $(\mathrm{N}=17)$; kegembiraan $(X)$ (mulai/tampak) terlihat $(\mathrm{N}=12)$, terlihat (ada/rasa/di wajah mereka) kegembiraan $(\mathrm{N}=4) ;$ menyaksikan (drama/keceriaan/kemeriahan dan) kegembiraan $(\mathrm{N}=7)$. 
Catatan penting lainnya adalah munculnya kesedihan sebagai kolokat khas kegembiraan. Temuan ini tampaknya menunjukkan bahwa kesedihan memiliki hubungan antonimi yang cukup kuat dengan kegembiraan, namun tidak dengan kesenangan dan kebahagiaan.

\section{Kolokat Khas untuk Keceriaan}

Nuansa semantis yang ditonjolkan oleh kolokat khas keceriaan (lihat Tabel 8) mirip dengan kegembiraan, utamanya yang terkait dengan intensitas, dan kekhususan ranah munculnya keceriaan. Namun, beberapa kolokat khas juga mengindikasikan nuansa semantis berbeda bagi keceriaan.

Salah satu ciri semantis yang khas adalah asosiasi keceriaan dengan kolokat yang mengacu pada ANAK, yaitu anak-anak (kolokat khas terkuat; mis. keceriaan anak-anak $[\mathrm{N}=$ 53], keceriaan bersama anak-anak [ $\mathrm{N}=3]$, keceriaan dengan anak-anak $[\mathrm{N}=3]$ ) dan anak (keceriaan anak $[\mathrm{N}=13]$; lihat $\mathrm{R}$ Notebook untuk pola kolokasi lebih lengkap). Asosiasi ini dapat mencerminkan adanya unsur keluguan dari keceriaan.

Tabel 8 Daftar 20 Kolokat Khas Teratas untuk Keceriaan di Gabungan Pangkalan Data Korpus Leipzig Bahasa Indonesia, Sketch Engine, dan WebCorp

\begin{tabular}{llrrrlll}
\hline \hline No. & Kolokat & $\mathbf{n}$ & exp & assocstr & p_binomial & p_holm & signif \\
\hline 1 & anak-anak & 91 & 19.123 & 42.698 & $2.003 \mathrm{e}-43$ & $1.460 \mathrm{e}-38$ & $* * *$ \\
\hline 2 & penuh & 119 & 46.831 & 21.976 & $1.057 \mathrm{e}-22$ & $7.707 \mathrm{e}-18$ & $* * *$ \\
\hline 3 & mengembalikan & 19 & 3.122 & 12.487 & $3.256 \mathrm{e}-13$ & $2.372 \mathrm{e}-08$ & $* * *$ \\
\hline 4 & semangat & 25 & 6.374 & 9.732 & $1.852 \mathrm{e}-10$ & $1.350 \mathrm{e}-05$ & $* * *$ \\
\hline 5 & masa & 31 & 9.366 & 9.502 & $3.151 \mathrm{e}-10$ & $2.296 \mathrm{e}-05$ & $* * *$ \\
\hline 6 & wajah & 37 & 13.269 & 8.653 & $2.222 \mathrm{e}-09$ & $1.619 \mathrm{e}-04$ & $* * *$ \\
\hline 7 & menambah & 20 & 5.203 & 7.721 & $1.902 \mathrm{e}-08$ & $1.385 \mathrm{e}-03$ & $* *$ \\
\hline 8 & sekolah & 13 & 2.602 & 7.016 & $9.638 \mathrm{e}-08$ & $7.019 \mathrm{e}-03$ & $* *$ \\
\hline 9 & anak & 39 & 16.391 & 6.901 & $1.255 \mathrm{e}-07$ & $9.142 \mathrm{e}-03$ & $* *$ \\
\hline 10 & kesegaran & 7 & 0.911 & 6.200 & $6.304 \mathrm{e}-07$ & $4.590 \mathrm{e}-02$ & $*$ \\
\hline 11 & lebanon & 7 & 0.911 & 6.200 & $6.304 \mathrm{e}-07$ & $4.590 \mathrm{e}-02$ & $*$ \\
\hline 12 & warna & 12 & 2.602 & 5.972 & $1.067 \mathrm{e}-06$ & $7.765 \mathrm{e}-02$ & $\mathrm{~ms}$ \\
\hline 13 & tetap & 17 & 5.203 & 5.412 & $3.872 \mathrm{e}-06$ & $2.819 \mathrm{e}-01$ & $\mathrm{~ns}$ \\
\hline 14 & suasana & 22 & 8.195 & 5.115 & $7.672 \mathrm{e}-06$ & $5.583 \mathrm{e}-01$ & $\mathrm{~ns}$ \\
\hline 15 & terpancar & 22 & 8.326 & 4.989 & $1.026 \mathrm{e}-05$ & $7.463 \mathrm{e}-01$ & $\mathrm{~ns}$ \\
\hline 16 & mewarnai & 10 & 2.342 & 4.652 & $2.228 \mathrm{e}-05$ & $1.000 \mathrm{e}+00$ & $\mathrm{~ns}$ \\
\hline 17 & pertunjukan & 5 & 0.650 & 4.429 & $3.725 \mathrm{e}-05$ & $1.000 \mathrm{e}+00$ & $\mathrm{~ns}$ \\
\hline 18 & korban & 7 & 1.301 & 4.278 & $5.269 \mathrm{e}-05$ & $1.000 \mathrm{e}+00$ & $\mathrm{~ns}$ \\
\hline 19 & lebaran & 7 & 1.301 & 4.278 & $5.269 \mathrm{e}-05$ & $1.000 \mathrm{e}+00$ & $\mathrm{~ns}$ \\
\hline 20 & menghiasi & 7 & 1.301 & 4.278 & $5.269 \mathrm{e}-05$ & $1.000 \mathrm{e}+00$ & $\mathrm{~ns}$ \\
\hline \hline
\end{tabular}


Data korpus menunjukkan bahwa anak-anak dapat berkaitan dengan kolokat khas lainnya, seperti mengembalikan dan korban, karena mereka dapat muncul dalam satu kalimat. Berikut ini adalah contoh konstruksi frase nomina keceriaan anak-anak yang mengisi slot objek langsung dari mengembalikan, dan anak-anak tersebut merupakan korban dari suatu bencana.

(7) Trauma healing tresebut guna mengembalikan keceriaan anak-anak korban erupsi Gunung Kelud yang selama seminggu terakhir berada di pengungsian. (case_48_sourceID_34_antara news)

(8) Di lokasi bencana, Rini ikut berbagi keceriaan dengan ratusan anak-anak korban bencana dengan bermain dan membagikan makanan. (corp_iNwsCrw2012_1M:963181)

Contoh di atas juga dapat mengungkap ciri kolektif dari keceriaan (layaknya kegembiraan), khususnya terkait dengan ranah BENCANA dan kelompok ANAK-ANAK. Kolokat lainnya juga menunjukkan kolektifitas dari keceriaan, khususnya kolokat yang mengacu pada tempat dan kegiatan yang memungkinkan interaksi sosial, yaitu sekolah, lebaran, dan pertunjukan. Kemudian, beberapa kolokat khas juga menunjukkan keterkaitan antara keceriaan dan konsepkonsep afektif/emosi, seperti kesegaran dan semangat. Kedua kolokat ini mengindikasikan kedekatan antara antusiasme dan keceriaan.

Selanjutnya, terdapat kolokat khas dalam pola metaforis yang merujuk pada konsepkonsep seperti intensitas dan hidup-nya (liveliness/vibrancy) perasaan yang diungkapkan oleh keceriaan. Penuh dan menambah dapat mengindikasikan intensitas yang tinggi serta usaha untuk meningkatkan intensitas keceriaan. Beberapa konstruksi yang dominan untuk penuh di antaranya konstruksi predikatif, yaitu penuh keceriaan $(\mathrm{N}=93)$, penuh dengan keceriaan $(\mathrm{N}=$ 9), penuh dengan kegembiraan dan keceriaan $(\mathrm{N}=3)$; untuk menambah, hanya terdapat tiga konstruksi, yaitu menambah keceriaan $(\mathrm{N}=18)$, menambah keasyikan keceriaan $(\mathrm{N}=1)$, menambah nuansa keceriaan $(\mathrm{N}=1)$.

Penuh dan menambah membentuk konseptualisasi yang terkait dengan metafora konseptual KECERIAAN ADALAH UNSUR/CAIRAN DALAM WADAH, yang juga tecermin pada kolokat khas lainnya, yaitu terpancar. Makna harafiah kata terpancar adalah terkait dengan cairan (https://kbbi.kemdikbud.go.id/entri/terpancar) dan mengindikasikan ketidakmampuan pengalam mengendalikan keceriaan dalam (wadah) diri sehingga terpancar/terungkapkan keluar: keceriaan (jelas) terpancar $(\mathrm{N}=8)$, keceriaan dan aura semangat terpancar $(\mathrm{N}=2)$, keceriaan dan kegembiraan terpancar $(\mathrm{N}=2)$. Jadi, unsur ekspresivitas juga mencirikan keceriaan. Konsep ekspresivitas serta hidup-nya keceriaan juga ditunjukkan oleh kolokat khas lain yang membentuk konstruksi metaforis, yaitu menghiasi, mewarnai, dan warna.

Keceriaan mengisi slot subjek dari menghiasi (keceriaan menghiasi $[\mathrm{N}=4]$ dan keceriaan terus/tetap/yang dulu selalu menghiasi $[\mathrm{N}=3]$ ) sehingga dapat dipandang sebagai instrument penghias seseorang atau suatu kejadian. Hal yang menarik dari ketujuh kolokasi dengan menghiasi tersebut adalah $85.71 \%$ (6 dari 7 sitiran) pengisi slot objek langsung dari menghiasi ialah wajah, yang juga merupakan salah satu kolokat khas untuk keceriaan. Keberadaan wajah sebagai kolokat khas dapat mendukung ciri keekspresifan dari keceriaan. Hal ini mengingat bahwa secara badaniah wajah merupakan salah satu anggota badan yang umumnya menjadi lokus perasaan/emosi seseorang yang tampak secara kasatmata (lihat G. P. W. Rajeg, 2019a, pp. 163-165, untuk ulasan terkait wajah dalam kajian emosi lintas bahasa).

Seperti menghiasi, keceriaan secara dominan muncul sebagai subjek dari mewarnai (keceriaan mewarnai $[\mathrm{N}=6]$, keceriaan juga/Ramadhan yang/yang begitu mewarnai $[\mathrm{N}=3]$ ). 
Satu konstruksi menunjukkan keceriaan sebagai objek yang diwarnai (mewarnai keceriaan $[\mathrm{N}=$ 1]). Konstruksi sintaksis kolokasi keceriaan dengan warna lebih beragam, misalnya warna yang membawa keceriaan $(\mathrm{N}=2)$, warna(-warni) keceriaan $(\mathrm{N}=2)$, warna menebar keceriaan $(\mathrm{N}=$ 1), warna aksen pemberi keceriaan $(\mathrm{N}=1)$ (periksa $\mathrm{R}$ Notebook untuk data lengkapnya).

\section{Kolokat Khas untuk Keriangan}

Konsep keriangan memiliki ciri serupa dengan keceriaan dan kegembiraan, khususnya terkait intensitas. Kolokat khas teratas bagi keriangan adalah penuh (periksa Tabel 9), yang paling sering muncul dalam pola metaforis penuh (dengan) keriangan $(\mathrm{N}=37)$. Dalam kolokasinya ini, keriangan juga muncul secara koordinatif dengan nomina yang menunjukkan ciri intensitas dari keriangan, yaitu penuh daya dan keriangan $(\mathrm{N}=1)$, penuh energi dan keriangan $(\mathrm{N}=1)$.

Tabel 9 Daftar 20 Kolokat Khas Teratas untuk Keriangan di Gabungan Pangkalan Data Korpus Leipzig Bahasa Indonesia, Sketch Engine, dan WebCorp

\begin{tabular}{|c|c|c|c|c|c|c|c|}
\hline No. & Kolokat & $\mathbf{n}$ & $\exp$ & assocstr & p_binomial & p_holm & signif \\
\hline 1 & penuh & 48 & 16.579 & 10.210 & $6.159 \mathrm{e}-11$ & $4.488 \mathrm{e}-06$ & $* * *$ \\
\hline 2 & kanak-kanak & 7 & 0.599 & 6.230 & $5.894 \mathrm{e}-07$ & $4.291 \mathrm{e}-02$ & $*$ \\
\hline 3 & politik & 5 & 0.368 & 4.986 & $1.032 \mathrm{e}-05$ & $7.508 \mathrm{e}-01$ & ns \\
\hline 4 & terakhir & 5 & 0.368 & 4.986 & $1.032 \mathrm{e}-05$ & $7.508 \mathrm{e}-01$ & $\mathrm{~ns}$ \\
\hline 5 & menggambarkan & 8 & 1.151 & 4.967 & $1.079 \mathrm{e}-05$ & $7.851 \mathrm{e}-01$ & $\mathrm{~ns}$ \\
\hline 6 & kehebatannya & 3 & 0.138 & 4.010 & $9.768 \mathrm{e}-05$ & $1.000 \mathrm{e}+00$ & $\mathrm{~ns}$ \\
\hline 7 & bocah & 4 & 0.368 & 3.567 & $2.711 \mathrm{e}-04$ & $1.000 \mathrm{e}+00$ & ns \\
\hline 8 & imajinasi & 3 & 0.184 & 3.423 & $3.772 \mathrm{e}-04$ & $1.000 \mathrm{e}+00$ & ns \\
\hline 9 & keseronokan & 3 & 0.184 & 3.423 & $3.772 \mathrm{e}-04$ & $1.000 \mathrm{e}+00$ & ns \\
\hline 10 & mengajar & 3 & 0.184 & 3.423 & $3.772 \mathrm{e}-04$ & $1.000 \mathrm{e}+00$ & $\mathrm{~ns}$ \\
\hline 11 & anak-anak & 17 & 6.770 & 3.331 & $4.665 \mathrm{e}-04$ & $1.000 \mathrm{e}+00$ & $\mathrm{~ns}$ \\
\hline 12 & khas & 4 & 0.414 & 3.328 & $4.701 \mathrm{e}-04$ & $1.000 \mathrm{e}+00$ & ns \\
\hline 13 & empat & 4 & 0.461 & 3.122 & $7.549 \mathrm{e}-04$ & $1.000 \mathrm{e}+00$ & ns \\
\hline 14 & kekonyolan & 3 & 0.230 & 3.041 & $9.105 \mathrm{e}-04$ & $1.000 \mathrm{e}+00$ & ns \\
\hline 15 & ketulusan & 3 & 0.230 & 3.041 & $9.105 \mathrm{e}-04$ & $1.000 \mathrm{e}+00$ & ns \\
\hline 16 & memancarkan & 4 & 0.507 & 2.942 & $1.143 \mathrm{e}-03$ & $1.000 \mathrm{e}+00$ & ns \\
\hline 17 & mendengar & 4 & 0.507 & 2.942 & $1.143 \mathrm{e}-03$ & $1.000 \mathrm{e}+00$ & ns \\
\hline 18 & hilang & 6 & 1.243 & 2.913 & $1.222 \mathrm{e}-03$ & $1.000 \mathrm{e}+00$ & ns \\
\hline 19 & menunjukkan & 7 & 1.704 & 2.875 & $1.334 \mathrm{e}-03$ & $1.000 \mathrm{e}+00$ & ns \\
\hline 20 & berbalut & 3 & 0.276 & 2.755 & $1.758 \mathrm{e}-03$ & $1.000 \mathrm{e}+00$ & ns \\
\hline 21 & kejayaan & 3 & 0.276 & 2.755 & $1.758 \mathrm{e}-03$ & $1.000 \mathrm{e}+00$ & ns \\
\hline
\end{tabular}

Kemiripan profil kolokasi lainnya antara keriangan dengan keceriaan adalah ketertarikan kuat dari kolokat yang merujuk pada konsep ANAK, yaitu kanak-kanak, bocah, dan anak-anak. Kedekatan ini juga dapat diartikan mencerminkan keluguan dari keriangan dan 
keceriaan. Sebagian besar pola kolokasi keriangan dengan leksikon ANAK muncul dalam konstruksi modifikasi, seperti keriangan anak-anak $(\mathrm{N}=8)$, keriangan khas anak-anak $(\mathrm{N}=4)$, keriangan (saat) bocah $(\mathrm{N}=4)$, keriangan masa kanak-kanak $(\mathrm{N}=2)$, keriangan dunia kanakkanak $(\mathrm{N}=1)$, dan keriangan hidup masa kanak-kanak $(\mathrm{N}=1)$.

Selanjutnya, terdapat konsep terkait yang khas untuk keriangan, yaitu ketulusan, kekonyolan, dan keseronokan. Ketiga konsep ini muncul dalam konstruksi koordinatif, seperti keseronokan dan keriangan $(\mathrm{N}=3)$, ketulusan dan keriangan $(\mathrm{N}=2)$, keriangan, kejenakaan, kekonyolan $(\mathrm{N}=1)$. Ketiga konsep ini juga dapat dikatakan sebagai salah satu pembeda semantis khas untuk keriangan jika dibandingkan dengan sinonim KEBAHAGIAAN yang telah dibahas sebelumnya.

Kemudian, terdapat pula kolokat khas verbal yang bersifat metaforis dan menunjukkan kemiripan ciri semantis antara keriangan dan keceriaan, yaitu ciri perseptif dan ekspresif kedua emosi ini. Kolokat yang dimaksud adalah menggambarkan, mendengar, dan menunjukkan. Beberapa contoh pola metaforisnya adalah menggambarkan keriangan $(\mathrm{N}=5)$, menggambarkan citra keriangan $(\mathrm{N}=1)$, menggambarkan kelincahan dan keriangan $(\mathrm{N}=1)$; menunjukkan keriangan $(\mathrm{N}=4)$, menunjukkan vitalitas enerji keriangan $(\mathrm{N}=1)$, menunjukkan gelagat keriangan $(\mathrm{N}=1)$; mendengar keriangan $(\mathrm{N}=1)$, mendengar hiruk-pikuk keriangan $(\mathrm{N}$ $=1$ ), dan mendengar teriakan keriangan $(\mathrm{N}=1)$. Kolokat verbal khas lain seperti memancarkan (memancarkan keriangan $[\mathrm{N}=4]$ ) pun dapat mencerminkan ekspresivitas metaforis dari keriangan, layaknya air yang meluncur keluar.

\section{SIMPULAN}

Tulisan ini menampilkan penerapan metode linguistik korpus kuantitatif dalam kajian semantik leksikal pada ranah emosi, khususnya sinonim pada medan leksikal KEBAHAGIAAN dalam bahasa Indonesia. Tujuan ini dibingkai dalam konteks menguji dan memberikan landasan empiris atas teori yang diajukan oleh Kövecses (1990) terkait pencirian semantis suatu konsep emosi. Teori tersebut adalah konsep-konsep terkait (related concepts) suatu emosi yang dibatasi sebagai konsep-konsep yang tersirat atau disyaratkan oleh konsep lainnya (Kövecses, 1990, hlm. 128). Konsep-konsep terkait ini dipandang membentuk jejaring konsep yang diasosiasikan dengan konsep emosi yang dikaji.

Dengan menggabungkan (i) pemahaman makna melalui pendekatan linguistik berdasar pemakaian (usage-based linguistics [UBL]), yaitu makna suatu kata tecermin dari distribusi konteks pemakaian kata tersebut dan (ii) pendekatan linguistik korpus kuantitatif, khususnya salah satu ragam dari analisis kolostruksional (collostructional analysis [CollAna]), yaitu analisis koleksem khas berganda (multiple distinctive collexeme analysis [MDCA]), istilah teoretis konsep terkait untuk pencirian semantis emosi dapat dibatasi secara empiris sebagai konsep-konsep yang dipicu oleh kolokat signifikan dan khas dari suatu emosi (dibandingkan dengan emosi lainnya) yang ditemukan berdasarkan data pemakaian bahasa dalam korpus.

Ulasan terhadap hasil dari MDCA terhadap lima sinonim yang dikaji (kebahagiaan, kesenangan, kegembiraan, keceriaan, dan keriangan) menunjukkan bahwa tiap-tiap sinonim tersebut memiliki kolokat khas yang dapat menunjukkan konsep-konsep terkaitnya. Daftar kolokat khas signifikan ini secara semantis mencirikan jejaring makna dan konsep berbeda di antara sinonim tersebut (misalnya: nuansa positif keilahian dan kesejahteraan untuk kebahagiaan vs nuansa keduniawian/fana untuk kesenangan). Namun, terdapat kemiripan konsep dari kolokat khas tersebut yang memungkinkan sinonim tertentu membentuk suatu 
gugusan tersendiri yang berbeda dengan sinonim lainnya. Sebagai contoh, sejumlah kolokat khas untuk keceriaan, kegembiraan, dan keriangan mencerminkan ciri intensitas dan ekspresivitas di antara ketiganya yang bukan merupakan ciri khas dari kesenangan dan kebahagiaan. Sebaliknya, kesenangan dan kebahagiaan memiliki kemiripan ciri berdasarkan kolokat khas metaforisnya yang menunjukkan kedua sinonim ini dipahami sebagai DESTINASI dari suatu PERGERAKAN, ciri yang tidak dimiliki oleh ketiga sinonim lainnya. Data empiris dalam korpus yang diolah melalui pendekatan kuantitatif dan UBL seperti dalam makalah ini memperkaya pencirian semantis sinonim emosi yang perbedaan dan persamaannya mungkin akan sulit untuk dikenali jika hanya berdasarkan pada intuisi kebahasaan peneliti.

\section{CATATAN}

Penulis berterima kasih kepada mitra bestari yang telah memberikan saran-saran untuk perbaikan makalah ini. Penulis juga berterima kasih kepada Alice Gaby, Howard Manns, Simon Musgrave, John Newman, Martin Hilpert, dan Anatol Stefanowitsch atas diskusi dan masukannya terkait penerapan metode CollAna untuk kajian sinonim leksikal dalam penelitian ini. Tidak satu pun dari mereka bertanggung jawab atas kekeliruan dan kekurangan yang ditemukan dalam makalah ini, selain tanggung jawab penulis sendiri. Penelitian ini sepenuhnya didanai oleh Monash University, Australia, melalui Monash International Postgraduate Scholarships (MIPRS) dan Monash Graduate Scholarships (MGS).

\section{DAFTAR PUSTAKA}

Bybee, J. L. (2013). Usage-based theory and exemplar representations of constructions. In T. Hoffmann \& G. Trousdale (Eds.), The Oxford handbook of Construction Grammar (pp. 49-69). Oxford University Press. https://doi.org/10.1093/oxfordhb/9780195396683.013.0004

Church, K. W., Gale, W., Hanks, P., \& Hindle, D. (1991). Using statistics in lexical analysis. In U. Zernik (Ed.), Lexical acquisition: Exploiting on-line resources to build a lexicon (pp. 115-164). Erlbaum.

Dąbrowska, E., \& Divjak, D. (Eds.). (2015). Handbook of Cognitive Linguistics. De Gruyter Mouton.

Desagulier, G. (2014). Visualizing distances in a set of near synonyms: Rather, quite, fairly, and pretty. In D. Glynn \& J. Robinson (Eds.), Corpus methods for semantics: Quantitative studies in polysemy and synonymy (pp. 145-178). John Benjamins Publishing Company.

Gevaert, C. (2007). The history of ANGER: The lexical field of ANGER from Old to Early Modern English [PhD thesis]. Katholieke Universiteit Leuven.

Gilquin, G. (2010). Corpus, cognition and causative constructions. John Benjamins Publishing Company.

Glynn, D. (2014a). Polysemy and synonymy: Cognitive theory and corpus method. In D. Glynn \& J. A. Robinson (Eds.), Corpus methods for semantics: Quantitative studies in polysemy and synonymy (pp. 7-38). John Benjamins Publishing Company.

Glynn, D. (2014b). The social nature of ANGER: Multivariate corpus evidence for context effects upon conceptual structure. In P. Blumenthal, I. Novakova, \& D. Siepmann (Eds.), Les émotions dans le discours =: Emotions in discourse (pp. 69-81). Peter Lang Edition.

Goldberg, A. E. (2013). Constructionist approaches. In T. Hoffmann \& G. Trousdale (Eds.), The Oxford Handbook of Construction Grammar (pp. 15-31). Oxford University Press. https://doi.org/10.1093/oxfordhb/9780195396683.013.0002 
Goldhahn, D., Eckart, T., \& Quasthoff, U. (2012). Building large monolingual dictionaries at the Leipzig Corpora Collection: From 100 to 200 languages. Proceedings of the 8th Language Resources and Evaluation Conference (LREC) 2012, 759-765. http://www.lrec-conf.org/proceedings/lrec2012/pdf/327_Paper.pdf

Gries, S. Th. (2009). Statistics for linguistics with $R$ : A practical introduction. Mouton de Gruyter.

Gries, S. Th. (2013). Data in construction grammar. In T. Hoffmann \& G. Trousdale (Eds.), The Oxford handbook of Construction Grammar (pp. 93-108). Oxford University Press. https://doi.org/10.1093/oxfordhb/9780195396683.013.0006

Gries, S. Th., \& Stefanowitsch, A. (2004). Extending collostructional analysis: A corpus-based perspective on "alternations." International Journal of Corpus Linguistics, 9(1), 97129.

Hilpert, M. (2006). Distinctive collexeme analysis and diachrony. Corpus Linguistics and Linguistic Theory, 2(2), 243-256.

Hilpert, M. (2008). Germanic future constructions: A usage-based approach to language change. John Benjamins Publishing Company.

Hilpert, M. (2014). Collostructional analysis: Measuring associations between constructions and lexical elements. In D. Glynn \& J. A. Robinson (Eds.), Corpus methods for semantics: Quantitative studies in polysemy and synonymy (pp. 391-404). John Benjamins Publishing Company.

Kövecses, Z. (1990). Emotion concepts. Springer.

Kövecses, Z. (1991). Happiness: A definitional effort. Metaphor \& Symbolic Activity, 6(1), 29.

Kövecses, Z. (2000). The concept of ANGER: Universal or culture specific? Psychopathology, $33,159-170$.

Kövecses, Z. (2015). Where metaphors come from: Reconsidering context in metaphor. Oxford University Press.

Krawczak, K. (2014). Shame and its near-synonyms in English: A multivariate corpus-driven approach to social emotions. In P. Blumenthal, I. Novakova, \& D. Siepmann (Eds.), Les émotions dans le discours =: Emotions in discourse (pp. 83-94). Peter Lang Edition.

Lakoff, G. (1993). The contemporary theory of metaphor. In A. Ortony (Ed.), Metaphor and thought (2nd ed., pp. 202-251). Cambridge University Press.

Lakoff, G., \& Johnson, M. (1980). Metaphors we live by. The University of Chicago Press.

Lakoff, G., \& Johnson, M. (1999). Philosophy in the flesh: The embodied mind and its challenge to Western thought. Basic Books.

Langacker, R. W. (2013). Essentials of Cognitive Grammar. Oxford University Press.

Levshina, N. (2015). How to do Linguistics with R: Data exploration and statistical analysis. John Benjamins Publishing Company. https://doi.org/10.1075/z.195

McEnery, T., \& Hardie, A. (2012). Corpus linguistics: Method, theory and practice. Cambridge University Press.

Oster, U. (2010). Using corpus methodology for semantic and pragmatic analyses: What can corpora tell us about the linguistic expression of emotions? Cognitive Linguistics, 21(4), 727-763. https://doi.org/10.1515/COGL.2010.023

Quasthoff, U., \& Goldhahn, D. (2013). Indonesian corpora (No. 7; Technical Report Series on Corpus Building). Abteilung Automatische Sprachverarbeitung, Institut für Informatik, Universität Leipzig. http://asvdoku.informatik.unileipzig.de/corpora/data/uploads/corpus-building-vol7-ind.pdf

R Core Team. (2019). R: A Language and Environment for Statistical Computing. R Foundation for Statistical Computing. https://www.R-project.org/

Rajeg, G. P. W. (2019a). Metaphorical profiles and near-synonyms: A corpus-based study of Indonesian words for HAPPINESS [PhD thesis, Monash University, Australia]. https://doi.org/10.26180/5cac231a97fb1 
Rajeg, G. P. W. (2019b, May 21). Distinctive Metaphors for HAPPINESS near-synonyms in Indonesian: A quantitative corpus-based approach [Paper]. Monash Linguistics and Applied Linguistics Seminar Series (S1 2019), Monash University, Australia. https://doi.org/10.26180/5cee3d5529452

Rajeg, G. P. W. (2019c). Happyr: The accompanying R package for Rajeg's (2019) PhD thesis titled "Metaphorical profiles and near-synonyms: A corpus-based study of Indonesian words for Happiness" (1.0) [R]. https://doi.org/10.5281/zenodo.3559457

Rajeg, G. P. W. (2020). Data dan r notebook untuk Linguistik korpus kuantitatif dan kajian semantik leksikal sinonim emosi bahasa indonesia. In Figshare. https://doi.org/10.6084/m9.figshare.12073065.v1

Rajeg, G. P. W. (2014). Metaphorical profiles of five Indonesian quasi-synonyms of ANGER: Multiple distinctive collexeme analysis. Proceedings of the International Congress of the Linguistic Society of Indonesia 2014, 165-170. https://doi.org/10.4225/03/58578ddba1fd2

Rajeg, G. P. W., Denistia, K., \& Rajeg, I. M. (2018). Working with a linguistic corpus using R: An introductory note with Indonesian negating construction. Linguistik Indonesia, 36(1), 1-36. https://doi.org/10.26499/li.v36il.71

Rajeg, G. P. W., \& Rajeg, I. M. (2019a). Analisis Koleksem Khas dan potensinya untuk kajian kemiripan makna konstruksional dalam Bahasa Indonesia. In I. N. Sudipa (Ed.), ETIKA BAHASA Buku persembahan menapaki usia pensiun: I Ketut Tika (Vol. 1, pp. 65-83). Swasta Nulus. https://doi.org/10.26180/5bf4e49ea1582

Rajeg, G. P. W., \& Rajeg, I. M. (2019b). Pemahaman kuantitatif dasar dan penerapannya dalam mengkaji keterkaitan antara bentuk dan makna. Linguistik Indonesia, 37(1), 13-31. https://doi.org/10.26180/5c6e1160b8d8a

Rajeg, I. M. (2013). Metafora emosi Bahasa Indonesia [Disertasi doktoral, Universitas Udayana]. https://doi.org/10.6084/m9.figshare.7886180

Shaver, P. R., Murdaya, U., \& Fraley, R. C. (2001). Structure of the Indonesian emotion lexicon. Asian Journal of Social Psychology, 4(3), 201-224. https://doi.org/10.1111/1467-839X.00086

Siahaan, P. (2008). Did he break your heart or your liver? A contrastive study on metaphorical concepts from the source domain ORGAN in English and in Indonesian. In F. Sharifian, R. Dirven, N. Yu, \& S. Niemeier (Eds.), Culture, body, and language. Conceptualizations of internal body organs across cultures and languages (pp. 45-74). Mouton de Gruyter.

Siepmann, D. (2014). Extent of collocational difference between languages: A corpus-based study of emotion nouns. In P. Blumenthal, I. Novakova, \& D. Siepmann (Eds.), Les émotions dans le discours =: Emotions in discourse (pp. 39-53). Peter Lang Edition.

Stefanowitsch, A. (2004). HAPPINESS in English and German: A metaphorical-pattern analysis. In Michel Achard \& Suzanne Kemmer (Eds.), Language, Culture, and Mind (pp. 137-149). CSLI.

Stefanowitsch, A. (2006). Words and their metaphors: A corpus-based approach. In A. Stefanowitsch \& S. Th. Gries (Eds.), Corpus-based approaches to metaphor and metonymy (pp. 63-105). Mouton de Gruyter.

Stefanowitsch, A. (2010). Empirical cognitive semantics: Some thoughts. In Dylan Glynn \& Kerstin Fischer (Eds.), Quantitative methods in cognitive semantics: Corpus-driven approaches (pp. 355-380). Mouton de Gruyter.

Stefanowitsch, A. (2011). Cognitive linguistics meets the corpus. In M. Brdar, S. Th. Gries, \& M. Ž. Fuchs (Eds.), Cognitive Linguistics: Convergence and Expansion (pp. 257-289). John Benjamins Publishing Company. 
Stefanowitsch, A. (2013). Collostructional analysis. In T. Hoffmann \& G. Trousdale (Eds.), The Oxford handbook of Construction Grammar (pp. 290-306). Oxford University Press. https://doi.org/10.1093/oxfordhb/9780195396683.013.0016

Stefanowitsch, A. (2014). Collostructional analysis: A case study of the English into-causative. In T. Herbst, H.-J. Schmid, \& S. Faulhaber (Eds.), Constructions collocations patterns (pp. 217-238). Walter De Gruyter, GmbH.

Stefanowitsch, A., \& Gries, S. Th. (2003). Collostructions: Investigating the interaction of words and constructions. International Journal of Corpus Linguistics, 8(2), 209-243.

Stefanowitsch, A., \& Gries, S. Th. (2005). Covarying collexemes. Corpus Linguistics and Linguistic Theory, 1(1), 1-43.

Stefanowitsch, A., \& Gries, S. Th. (2009). Corpora and grammar. In A. Lüdeling \& M. Kytö (Eds.), Corpus linguistics: An international handbook (Vol. 2, pp. 933-951). Mouton de Gruyter.

Tummers, J., Heylen, K., \& Geeraerts, D. (2005). Usage-based approaches in Cognitive Linguistics: A technical state of the art. Corpus Linguistics and Linguistic Theory, 1(2), 225-261.

Wickham, H., Averick, M., Bryan, J., Chang, W., McGowan, L., François, R., Grolemund, G., Hayes, A., Henry, L., Hester, J., Kuhn, M., Pedersen, T., Miller, E., Bache, S., Müller, K., Ooms, J., Robinson, D., Seidel, D., Spinu, V., ... Yutani, H. (2019). Welcome to the Tidyverse. Journal of Open Source Software, 4(43), 1686. https://doi.org/10.21105/joss.01686

Wilson, P. A., \& Lewandowska-Tomaszczyk, B. (2017). Pride in British English and Polish: A cultural-linguistic perspective. In F. Sharifian (Ed.), Advances in cultural linguistics (pp. 247-288). Springer Berlin Heidelberg. https://doi.org/10.1007/978-981-10-40566_12

Yuditha, T. (2010, April 24). Indonesian metaphorical conceptualizations of Anger: Does Anger taste delicious or disgusting? [Paper]. The 8th Annual Atma Jaya Linguistics Conferences (KOLITA), Atma Jaya University, Jakarta, Indonesia. http://lingweb.eva.mpg.de/jakarta/docs/Indonesian_Metaphorical_Conceptualizations_o f_Anger,_Tessa_Yuditha.pdf

Yuditha, T. (2013, February 17). Indonesian metaphorical conceptualizations of ANGER, LOVE, and HATE: An overview [Paper]. International Workshop on "Special Genres" in and around Indonesia, Tokyo, Japan. http://repository.tufs.ac.jp/bitstream/10108/75521/1/B130_123-142.pdf

\footnotetext{
1 Representasi berbeda dari $2.003128510 \mathrm{e}-43$ adalah 0.0000000000000000000000000000000000000000002003129

2 Pola pencariannya menggunakan teknik yang disebut regular expressions (disingkat RegEx).

3 Daftar keseluruhan stopwords dibagikan terbuka pada repositori data dan kode R dari makalah ini (G. P. W. Rajeg, 2020)

4 Koreksi $p$-value menggunakan metode Holm atau yang lebih konservatif seperti Bonferroni bertujuan untuk membatasi ambang batas signifikansi statistik yang diterapkan untuk uji signifikansi berulang; pada kasus CollAna secara umum, uji signifikansi dilakukan untuk tiap-tiap kolokat dalam data sehingga terdapat lebih dari satu uji signifikansi (multiple significance testing). Uji signifikansi berulang seperti ini berpeluang lebih tinggi untuk menemukan lebih banyak "hasil yang tampaknya signifikan tapi sebenarnya hanya sebuah kebetulan" (“a seemingly significant result has come about by accident”) (Stefanowitsch, 2011, hlm. 275, catatan kaki no. 5). Oleh karena itu, adanya koreksi Holm ataupun Bonferroni untuk $p$-value dari uji signifikansi berluang bisa menyebabkan tidak semua $p$-value hasil dari uji signifikansi awal akan tetap signifikan setelah dikoreksi.
} 
5 Tabel $n$-gram dari kolokat khas yang dibahas dapat dilihat pada R Notebook pendamping makalah ini (G. P. W. Rajeg, 2020, dan lihat juga dalam versi daring: https://gederajeg.github.io/kolokat_khas/). Hal ini karena tidak semua pola dan konstruksi dari kolokat khas akan ditampilkan dalam makalah, untuk mengakomodir batasan ruang tulis yang diberikan. 